Article

\title{
Improvement of Services for People with Disabilities by Public Administration in Silesian Province Poland
}

\author{
Radosław Wolniak *(D) and Bożena Skotnicka-Zasadzień \\ Faculty of Organisation and Management, Silesian University of Technology, 41-800 Zabrze, Poland; \\ bozena.skotnicka@polsl.pl \\ * Correspondence: rwolniak@polsl.pl
}

\section{check for}

updates

Citation: Wolniak, R.;

Skotnicka-Zasadzień, B.

Improvement of Services for People

with Disabilities by Public

Administration in Silesian Province

Poland. Sustainability 2021, 13, 967.

https: / doi.org/10.3390/su13020967

Received: 11 November 2020

Accepted: 14 January 2021

Published: 19 January 2021

Publisher's Note: MDPI stays neutral with regard to jurisdictional claims in published maps and institutional affiliations.

Copyright: (c) 2021 by the authors. Licensee MDPI, Basel, Switzerland. This article is an open access article distributed under the terms and conditions of the Creative Commons Attribution (CC BY) license (https:// creativecommons.org/licenses/by/ $4.0 /)$.

\begin{abstract}
The publication presents the results of extensive research analyzing the satisfaction with the services of people with disabilities. The goal of the study was to analyze the level of disabled customer service by city councils at the example of the Silesian Province in Poland and to determine the factors that affect the quality of service studied. The research was carried out in 33 municipal offices located in Poland in the Silesian Province on a sample of 2846 people with disabilities. The research shows that disability type has a significant impact on the perceived level of disabled customer service. Moreover, the age of the disabled person has a significant impact on the perceived level of service quality. It turns out that the younger people with disabilities are, the better they assess the level of quality of services provided by the surveyed offices.
\end{abstract}

Keywords: quality of services; society 5.0; smart city; disabled people; disability; city hall; sustainable community

\section{Introduction}

The contemporary development of the concept of Society 5.0 requires sustainability at every level of its functioning [1-8]. Particular attention should be paid to customer groups that were previously excluded or almost ignored by certain types of public services. People with disabilities are such a group. The people with disability have special needs which we should know in the process of sustainable urban development.

The problems of people with disability are very important nowadays because they are very specific and also common with many of today's policies, for example, European Union policies. The European Union Disability Strategy focused on eight priority areas: accessibility, participation, equality, employment, education and training, social protection health and external action. Fulfilment of those areas can bring a better quality of life for disables [9]. The level of services in public administration can influence many of the mentioned areas. An especially important problem is the accessibility to the municipal office buildings, the participation of the people with disability without barriers and equality-the service on the same level regardless of the level of disability. In addition, the new European accessibility act brings information about the role of the fulfilment of disabling needs in the European Union. This act points out that all service for people with disabilities should be done with adequate quality [10]. Especially in the case of accessibility of municipal office web pages, the accessibility for peoples with a disability is regulated by special EU directive from 2016. We think the problem of quality of municipal services for people with disabilities is very important from a social point of view and also is not well known and not exhaustively described in the scientific literature. It is a research gap worth investigating. It states that better accessibility should lead to a better quality of life for peoples with a disability because of easier access to public services [11]. This publication presents the results of research on the quality level of services rendered for people with disabilities. The research was conducted on the sample of municipal offices located in Poland in the Silesian Province. On the basis of identified research gap we formulate the goal of our research. 
The main goal of the conducted study was to analyze the level services in municipal offices perceived by customers with disability on the example of the Silesian Province in Poland. The secondary goals of the study were:

- to investigate the impact of social and disability variables of the perceived level of quality of life,

- to investigate if the comparison of the quality level of investigated municipal office with other municipal offices affects the perceived quality of services.

- We think that analysis of the level of quality peoples with a disability can improve the sustainable development of the urban area from the adjustment of municipal offices service point of view. This is an important part of building sustainable communities adjusted to all group of peoples.

Based on the identified research gap and research goals, we formulated our hypnosis's. We wanted to know if social and disability variables have an impact on the perceived quality of life because we think that this problem is important in the process of public service planning. When we know what kind of people with disability (from the degree of disability, disable type, education or age point of view) perceive the service as good or bad we can adjust the services and try to prepare special service of a particular type of people. The following hypotheses were made in the research:

Hypothesis 1 (H1): Social and disability variables have a significant impact on the perceived level of quality of disabled customer service.

Hypothesis 2 (H2): The degree of disability has a significant impact on the perceived level of quality of disabled customer service.

Hypothesis 3 (H3): Disability type has a significant impact on the perceived level of disabled customer service.

Hypothesis 4 (H4): Education of a disabled person has a significant impact on the perceived level of quality of disabled customer service.

Hypothesis $\mathbf{5}$ (H5): The age of the disabled person has a significant impact on the assessment of the perceived level of service quality.

Hypothesis 6 (H6): The assessment of a given office compared to other offices has a significant impact on the perceived level of quality of services provided by a given city hall for people with disabilities.

\section{Literature Review}

\subsection{Disabilities and Their Characteristic}

Persons with disabilities function in all societies worldwide. The share of people with disabilities in the global population in individual countries, depending on the definition of the term "disability" and the way data is collected and classified, ranges from a dozen or so per cent to one-fifth of all humanity [12-15]. The World Health Organization (WHO) introduced the following concept of disability, taking into account the state of human health "Impairment-any loss of fitness or irregularity in the structure or functioning of the body in psychological, psychophysical or anatomical terms, disability—any limitation or inability (resulting from disability) of conducting activity living in a way or to the extent considered atypical for people, limitations in the performance of social roles, disability of a specific person resulting from or preventing the full fulfilment of a social role corresponding to age, sex and in accordance with social and cultural conditions [16-19]. Another definition of disability is presented in the Act on Vocational and Social Rehabilitation and Employment of Disabled People: "Disability is a permanent or temporary inability to fulfil social roles due to permanent or long-term violation of the body's fitness, in particular causing an inability to work" [20,21]. This Act defines three degrees of disability: severe, moderate and light. On 1 August 1997, the Sejm [the House] of the Republic of Poland adopted the Charter on 
the Rights of Persons with Disabilities, which presents the following definition of disability: persons with disabilities, i.e., persons whose physical, mental or mental fitness permanently or periodically impedes, restricts or prevents everyday life, study, work and performing social roles in accordance with legal and customary norms [22]. The 2006 Convention on the Rights of Persons with Disabilities recognized that "Disability is an evolutionary concept and results from the interaction between people with dysfunctions and barriers resulting from human attitudes and the environment that make it difficult for them to participate fully and effectively in the social life on an equal basis with other people" [23]. Following this train of thought, in Convention No. 159, of 2006, concerning vocational rehabilitation and employment of disabled people in Art. 1, the following definition of a disabled person is included. A disabled person is a person whose possibilities of obtaining and maintaining adequate employment and professional promotion are significantly limited as a result of the properly diagnosed loss of physical or mental abilities [24]. According to the Declaration on the Rights of Persons with Disabilities of 1975, the term disabled person means any person who, as a result of a deficit of his or her physical or mental abilities, innate or acquired, is unable to provide himself or herself, partly or completely, with the necessary conditions for his or her individual or social life [25]. Based on the review of the aforementioned definitions, it appears that there is no clear definition of a disabled person. Both in the world and Poland, there is no unambiguous and acceptable term for a disabled person. This results in the fact that in one country a person may be disabled, and in another, they would not receive such status [26]. The problem is quite significant, especially in the EU countries because so far, no uniform definition of a disabled person has been formulated, which would apply in all Member States. Nevertheless, both globally and in the EU countries including Poland, efforts are being made to precisely indicate aspects of disability and identify a disability. Based on the classification of disability and all factors that define disabilities, the disability models that have been developed so far, including medical, functional and social models [27-34]. Table 1 presents the characteristics of disability models.

Functional disability (speaking, walking, thinking, memory, etc.) is, in this approach, a dynamic disability that occurs in separate stages, which can occur consecutively or simultaneously [35-37].

Table 1. Characteristics of disability models.

\begin{tabular}{|c|c|c|c|}
\hline Comparison Categories & Medical Model & Functional Model & Social Model \\
\hline Historical perspective & $\begin{array}{l}\text { The roots of the biomedical } \\
\text { model date back to the } \\
\text { Renaissance period }\end{array}$ & $\begin{array}{l}\text { The first such model was created in } \\
1965\end{array}$ & $\begin{array}{l}\text { Its roots are linked to the } \\
\text { emergence of emancipation } \\
\text { organizations of people with } \\
\text { disabilities in Great Britain at } \\
\text { the turn of the 1970s and 1980s }\end{array}$ \\
\hline Definition of disability & $\begin{array}{l}\text { WHO definition of } \\
\text { impairment: any reduction in } \\
\text { performance or any } \\
\text { irregularity in the structure or } \\
\text { functioning of the body in } \\
\text { psychological, physical or } \\
\text { anatomical terms and the } \\
\text { psychosocial consequences of } \\
\text { this lack of impairment. } \\
\text { Disability = handicap }\end{array}$ & $\begin{array}{l}\text { WHO definition of disability: any } \\
\text { restriction or inability to lead an } \\
\text { active life in a way or to the extent } \\
\text { considered to be typical of a person } \\
\text { of a similar age and of the same sex. } \\
\text { WHO definition of impediment: } \\
\text { limitation or impossibility of full } \\
\text { implementation of social roles } \\
\text { corresponding to age, sex and in } \\
\text { accordance with social and cultural } \\
\text { conditions } \\
\text { Disability = handicap }\end{array}$ & $\begin{array}{l}\text { Lack or limitation of human } \\
\text { activity caused by } \\
\text { contemporary social } \\
\text { organization, which does not } \\
\text { take into account the needs of } \\
\text { people with physical } \\
\text { impairments and learning } \\
\text { difficulties, thus excluding } \\
\text { them from the mainstream of } \\
\text { social life. } \\
\text { Impairment = handicap }\end{array}$ \\
\hline
\end{tabular}


Table 1. Cont.

\begin{tabular}{|c|c|c|c|}
\hline Comparison Categories & Medical Model & Functional Model & Social Model \\
\hline $\begin{array}{l}\text { Understanding the } \\
\text { process of loss of fitness }\end{array}$ & $\begin{array}{l}\text { Pathological impairment of } \\
\text { the person's body, which is } \\
\text { synonymous with limitations }\end{array}$ & $\begin{array}{l}\text { Deteriorating health, which } \\
\text { translates into functional } \\
\text { limitations, e.g., walking, speaking }\end{array}$ & $\begin{array}{l}\text { Deprivation of the capacity to } \\
\text { act due to societal pressures }\end{array}$ \\
\hline $\begin{array}{l}\text { Determinants of } \\
\text { disability }\end{array}$ & $\begin{array}{l}\text { Genetic, teratogenic factors, } \\
\text { pathogens, injuries and } \\
\text { mechanical damage }\end{array}$ & $\begin{array}{l}\text { Biological, social and personal, } \\
\text { independent or interdependent in } \\
\text { various model modifications }\end{array}$ & $\begin{array}{l}\text { Social prejudices and physical } \\
\text { barriers, pressure from the } \\
\text { "fit" majority }\end{array}$ \\
\hline Criterion of disability & $\begin{array}{l}\text { Theoretical biological norm, } \\
\text { healthy and properly } \\
\text { functioning body }\end{array}$ & $\begin{array}{l}\text { Theoretical functional norm: } \\
\text { activity, efficiency and fulfillment of } \\
\text { social roles in }\end{array}$ & $\begin{array}{l}\text { Theoretical social norm: } \\
\text { participation and social } \\
\text { inclusion }\end{array}$ \\
\hline Causal attribution & $\begin{array}{l}\text { Internal: pathology within the } \\
\text { individual }\end{array}$ & $\begin{array}{l}\text { Interactive, interaction between the } \\
\text { internal and the external }\end{array}$ & $\begin{array}{l}\text { External: oppression from a } \\
\text { "normal" society }\end{array}$ \\
\hline Liability attribution & $\begin{array}{l}\text { External: doctors are } \\
\text { responsible for the changes } \\
\text { made }\end{array}$ & $\begin{array}{l}\text { Internal: taking responsibility for } \\
\text { yourself, including taking } \\
\text { advantage of treatment options and } \\
\text { adapting the environment. } \\
\text { External: supporting the above } \\
\text { process }\end{array}$ & $\begin{array}{l}\text { External: society must change, } \\
\text { but people with disabilities } \\
\text { should initiate these changes }\end{array}$ \\
\hline Support forms & Medicalization & Support & Reinforcement \\
\hline Means of assistance & $\begin{array}{l}\text { Healing and compensatory } \\
\text { influence directed at the } \\
\text { source and effects of bodily } \\
\text { impairment }\end{array}$ & $\begin{array}{l}\text { Complex individual supportive } \\
\text { effect, treatment and adaptation } \\
\text { process to the disabled person's } \\
\text { environment, assistive technologies, } \\
\text { accommodative tools and } \\
\text { techniques }\end{array}$ & $\begin{array}{l}\text { Removing barriers, universal } \\
\text { design, fighting against } \\
\text { prejudice and social exclusion, } \\
\text { self-advocacy }\end{array}$ \\
\hline Personal perspective & $\begin{array}{l}\text { People involved in the } \\
\text { treatment and rehabilitation } \\
\text { and compensation process }\end{array}$ & $\begin{array}{l}\text { People in close and professional } \\
\text { relationships with people with } \\
\text { disabilities }\end{array}$ & $\begin{array}{l}\text { People with disabilities aware } \\
\text { of the properties of the world } \\
\text { around them }\end{array}$ \\
\hline
\end{tabular}

Source: [38-40].

In each model presented (Table 1), disability is seen as a loss of fitness. Classification criteria that are the basis for a person to be considered disabled are related to biological, social and functional standards [41].

\subsection{Barriers and Problems with the Services by the Public Administration}

Due to the subject of this article, the social context of the problem of people with disabilities is further discussed. In recent years, there have been positive changes in public awareness related to the place and role of disabled people in society. These changes are associated with the fight against the exclusion of people with disabilities and with the increase in social programs that draw attention to the social and economic integration of all people functioning in society, including people with disabilities [42-45]. The latest UN documents on people with disabilities contain provisions and solutions for equal opportunities and social and professional promotion of people with disabilities. In 2001, the International Classification of Functioning, Disability and Health-IFC was presented at the World Health Assembly regarding the social context of disability issues. This document indicates that disability affects all of humanity and that social minorities should not be burdened with problems related to the disability [46-50]. The summary of this document concludes that anyone can experience deterioration and become disabled. In recent years, in addition to the document presented above, there have also been others that concern people with disabilities and normalize their lives. Among them, the most important are the Universal Declaration of Human Rights, the Declaration of the Rights of the Child, the 
Convention on Human Rights, the World Declaration of Education for All, Standard Rules for the Equalization of Opportunities for People with Disabilities, the Salamanca Statement on Principles, Policy and Practice in Special Needs Education and a Framework for Action, the Polish Constitution and the Madrid Declaration [51-53].

The Madrid Declaration is currently one of the most important documents containing issues related to people with disabilities [54]. This document assumes the following:

- Disability is a matter of human rights.

- $\quad$ People with disabilities demand equal opportunities, not pity.

- Barriers in society lead to discrimination and social exiting.

- $\quad$ People with disabilities are a diverse group of people.

- Nondiscrimination + positive action = social inclusion.

In Poland, the Sejm (the House) of the Republic of Poland in the Charter of the Rights of Persons with Disabilities included information that, according to legal and customary norms, "disabled persons have the right to an independent, autonomous and active life and may not be subject to discrimination" [55]. Based on this provision, all disabled people have the right to "access to goods and services allowing full participation in social life, living in an environment free of functional barriers, including access to offices, polling stations and public facilities, free movement, access to information, opportunities for interpersonal communication and participation in social, cultural and artistic life." Pursuant to the provisions in the Charter of the Rights of Persons with Disabilities, people with disabilities must have the right and equal access to services facilitating participation in social life [56-60]. Public services are among the services that disabled people must use. The use of public administration services by disabled people is not always free from obstacles and barriers that may be encountered during visits to offices. The most important obstacles include: finding and obtaining forms and necessary information, both during visits to these facilities and when using public e-services, moving people with disabilities around public administration offices, no lifts adapted for the disabled [61].

Some of the barriers that disabled people may encounter when using public administration offices are:

- Logistic barriers related to arrival at the public administration office.

- Architectural barriers that are associated with problems with the mobility of a disabled person around the building.

- Organizational and information barriers.

Logistic barriers are primarily associated with disabled people arriving to the office, using public transport, waiting for a bus or tram and having to change means of transportation. People with disabilities who drive their own vehicles may have problems trying to find a parking space close to the entrance to public administration offices.

Organizational and information barriers are associated with a direct visit to public administration office or with the use of public e-services. These barriers are easiest to remove by using the following facilities for people with disabilities: easily navigated and legible websites, which should allow people with disabilities conclude all formalities in public administration offices without leaving home, e.g., download and fill out relevant forms; posting legible signs on appropriate rooms in public administration buildings; large and clear information boards; properly marked routes to individual departments in public administration offices; a properly organized reception so that disabled people can easily get all necessary information; providing the customer service office with visual aids (letter templates, building plans); people working in such offices should know sign language and be trained to work with people with varying degrees of disability. Hiring a disabled person's assistant who would help in managing all necessary matters.

Architectural barriers that hinder the use of public administration buildings for people with disabilities are most often associated with the design and construction of buildings. To eliminate such barriers, the following solutions can be proposed: 
- building vehicles and ramps,

- ramps without curbs,

- installing elevators in buildings,

- adapting door openings and doors to the needs of disabled people moving in wheelchairs,

- appropriate wide transportation routes and corridors without thresholds in buildings,

- $\quad$ toilets adapted for the needs of the disabled.

- $\quad$ suitably adapted customer service offices for people with various disabilities,

- handrails installed at the appropriate height,

- providing bumps on surfaces allowing blind people to orient themselves and detectable warnings at appropriate navigation points [62-64].

The terminological and definitional considerations presented above have shown that the quality of life of people with disabilities is perceived in the category of interdisciplinary issues concerning the economic, medical and social plane, as shown on the example of disability models (Table 1). In recent years, many works on theoretical issues related to the quality of life of people with disabilities have been presented in world and Polish literature. The main purpose of these publications was to determine to what extent the types and degree of disability affect the quality of life. In addition, researchers are trying to determine what factors may affect the quality of life of people with disabilities. According to M. Garbat and M. A. Paszkowicz [65], as well as P. Borowiecki, [66] the quality of life of people with disabilities is influenced by external factors, which include: architectural and technical barriers, such as rehabilitation equipment, door width, access to public institutions, transport, and moving around by public transport and access to the Internet, a computer. In addition to the above-mentioned external factors, the quality of life of people with disabilities is also affected by the lack of employment, insufficient funds for rehabilitation and the quality of contacts with relatives. K. Pawłowska-Cyprysiak, M. Konarska and D. Żołnierczyk-Zreda [67] believe that the quality of life of people with disabilities is largely influenced by socio-demographic factors such as place of residence, level of education, duration of disability, age and marital status. The literature also included research on the sense of the quality of life of people with disabilities. Z. Palak, D Chomicz and A. Pawlak [68] used the Sense of Quality of Life Questionnaire by Schalock and Keith in their research. This questionnaire highlights the following factors: a sense of social integration, independence and self-reliance. The research conducted by the authors has shown that the type of disability has a large impact on the sense of the quality of life. The problem of the sense of the quality of life of people with disabilities was also investigated by R Smoleń [69]. In their research, they measured the sense of the quality of life of young people with intellectual disabilities and used the Deiner and Emmons Scale of Satisfaction with Life. Based on the presented research - the sense of the quality of life, it was found that the social and family spheres are the greatest problems for people with disabilities. The conducted query allowed for the collection of literature related to the level of quality of life of people with disabilities due to medical, economic and social factors that affect the perception and sense of the quality of life by people with disabilities. There are no studies in the literature showing how the quality of provided services is assessed by people with disabilities who have to use public administration, e.g., municipal offices, daily.

On this basis, a research gap was identified related to the improvement of the quality of services provided to persons with disabilities by the public administration. This issue is important from the point of view of improving the quality of life of people with disabilities and their social integration [70-77].

\section{Methods and Materials}

The research analyzed in the paper was carried out in Poland using the Silesian Province as an example. The Silesian Province is the most densely populated in Poland, with the highest percentage of cities. In the Silesian Province, there are 71 cities. Based on pilot studies we calculated the minimal size of the sample. In our research, there was 
20 cities and 1200 respondents. The research was carried out on a randomly selected sample of 33 cities located in the Silesian Province from the list of 71 existing cities.

Within each city, the study enrolled a random sample of disabled people surveyed. In total, after rejecting incorrectly completed surveys, 2846 correctly completed surveys by disabled persons using the municipal office services in the examined cities of the Silesian Province were received. We recruited subjects from various associations of disabled people functioning in Silesian province. We achieved 3 incomplete questionaries' which could not be used in the analysis. This bias has not a significant impact on the results.

In the conducted research, five types of disability were distinguished with the following structure of respondents:

- $\quad$ educed sensory performance-lack, damage or disruption of the functions of sensory analyzers (these include blind, visually impaired, deaf and hearing-impaired people with visual and auditory perception disorders) - a total of 644 respondents;

- reduced intellectual performance-intellectual disability-182 respondents;

- reduced efficiency of social functioning - disorders of nervous and emotional balance399 respondents;

- reduced communication efficiency—difficult verbal contact (speech disorders, autism, stuttering)—444 respondents;

- reduced mobility_-people with locomotor dysfunction-1153 respondents.

Twenty-four respondents did not state their disability in the survey.

Using the expert, Delphi method for the quality of services, 32 variables were distinguished in the research. In the expert method, we send questionnaires to 30 experts dealing with problems of people with disability in Poland [78-82]. Ten of them were people with disability, ten were people from municipal offices-plenipotentiaries for people with disabilities and ten academic specialists from the people with disabilities quality of life field. We prepared questionnaires', based on the quality of life literature, with many variables connected to the quality of service measure. The expert assessed which variables are important. We use in our research dose variable which was seen as important by experts. Next, after research, we calculated alfa-Cronbach to analyses the reliability of coefficient and based on the results, we decided that we can use the questionnaire in research $[83,84]$.

We distinguished the following variables:

- J1-modern office equipment in the municipal office,

- J2-the appearance and neatness of officials,

- J3-the attractiveness of information materials,

- J4-legibility of the website,

- J5-office building appearance,

- J6-timely delivery of the service,

- J7-afternoon and weekend office hours,

- J8 - settling matters by office employees the first time,

- J9-quick resolution of customer issues,

- J10-office workers do everything to bring the case to an end,

- J11-the willingness to provide customers with information,

- J12-office employees trying to help people with disabilities,

- J13 - the willingness to help customers,

- J14-the speed of responding to emails,

- J15-keeping the customers informed about the progress of the case,

- J16-website update speed,

- J17-competence of office staff,

- J18-office staff inspiring trust,

- J19-the level of care for the security of customer's personal data,

- J20-employee attitude towards the customer (courtesy, friendliness),

- J21-directing the customer to the appropriate department,

- J22-individual approach to customers,

- J23-service to the last customer, even when office hours are over, 
- J24-putting the good of the customer as the primary goal,

- J25-forbearance and patience with customers,

- J26-knowledge of good practices for servicing disabled people by officials,

- J27-officials turn to people with hearing impairments using a suitable device,

- J28-officials talk to the hearing impaired in a separate room,

- J29-the office has an employee who knows sign language,

- J30-officials can serve customers with a service dog,

- J31-officials can serve customers with a service dog,

- J32-the office is equipped with special frames facilitating the signing of the document.

We measured disability severity dividing disability into three levels: significant, moderate and low. This division is by polish low was this division is commonly used.

All variables regarding the quality level were rated on a typical Servqual 1-7 scale, wherein the case of expected quality 1 means that the variable is not expected by the customer, while 7 means that it is very strongly expected; in the case of perceived quality, 1 means that the variable is implemented by the municipal office at a very poor level, while 7 means that it is implemented at a very good level. Various types of quantitative methods of statistical data analysis were used to analyze the results of research collected during actual research. Calculations for the needs of the study were made using an Excel spreadsheet and Statistica 13.0 package.

The normality of variables was determined using the following tests: KolomongorovSmirnov test for large trials and Shapiro-Wilk test for small trials. In most cases, because division and nominal scales were used, the examined variables could not be considered normal; therefore, nonparametric tests were used for their further analysis. For the dependence of categorized traits, which usually cannot be treated as normal variables and do not meet the Shapiro-Wilk and Kolomongorov-Smirnov normality tests with the Lilliefors correction, the nonparametric ANOVA Kruskal-Wallis test was used, as it does not require a normal distribution of the examined traits. Mann-Whitney $U$ test was used to assess differences between the studied groups in situations where variable distributions were not normal.

Because one of the variables was nominal when calculating the coefficients of dependence between variables, the Cramér's V convergence coefficient was calculated for tables with different numbers of rows and columns.

The research tool developed was tested using Cronbach's alpha measure. This factor takes values from the range [0,1]. It is the bottom measure of the reliability estimator and is used for one-dimensional scales. It is recommended that for ordinal scales related to attitude measurement it should be at least 0.7 . For all examined variables, the obtained scale reliability was assumed to be above 0.7 .

\section{Results}

In the case of analyzing issues related to disabled customer service, the total level of quality is calculated by the difference between perceived and expected quality. Figure 1 presents the results of research on the calculated level of quality of disabled customer service for individual 32 variables included in the analysis. To assess the level of variables, the linguistic variables characterized in the previous section were used.

If possible, please copy this symbol here "-" to use it as the minus sign. Among the variables examined, concerning the level of quality of disabled customer service in municipal offices, the following issues were assessed at a good level:

- $\quad$ well-groomed and neat appearance of officials ( -0.79 rating);

- renovated and attractive office building $(-0.84)$. 


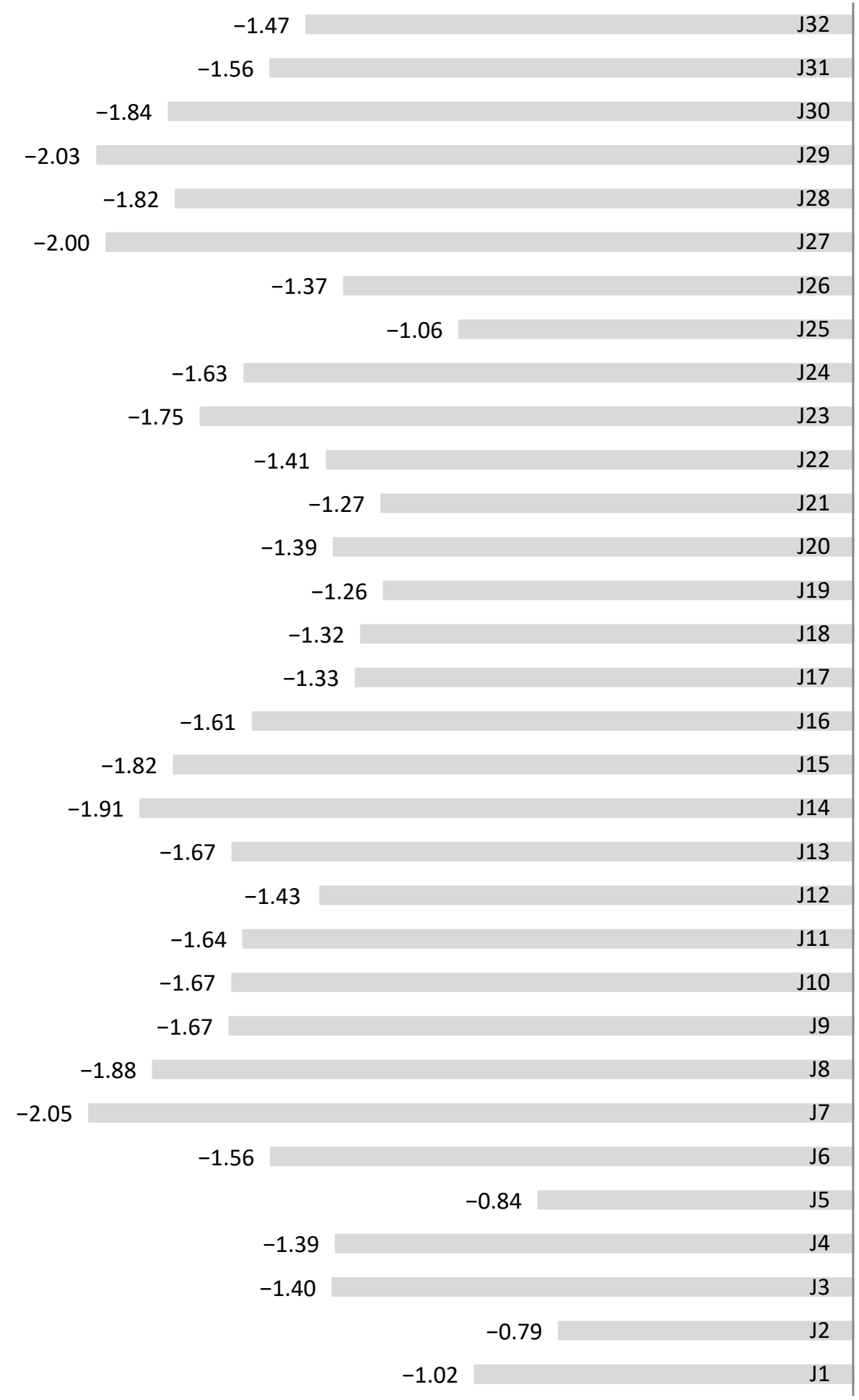

Figure 1. The level of customer with a disability service in the studied municipal offices. Source: own work.

At the very poor level, two variables were assessed-the office opening hours $(-2.05)$ and sign language skills by the office employees $(-2.03)$. Respondents point out that the office should also be open in the afternoon and on weekends. Interestingly, this variable got the lowest rating, even though it was one of the least significant in terms of customer expectations. Nevertheless, despite low expectations, a very poor assessment of perceived 
quality means that this is the problem with the worst level of quality. Variables that have been assessed as bad include:

- $\quad$ support for people with hearing impairments using a suitable device $(-2)$;

- $\quad$ speed of response to emails (-1.91) - it is worth paying attention to this problem, especially in the context of using e-administration as a solution to the problem of inconvenient office opening hours;

- $\quad$ proper customer service the first time $(-1.88)$;

- $\quad$ service for people with a service $\operatorname{dog}(-1.84)$;

- talking to a person with hearing impairment in a separate room $(-1.82)$;

- $\quad$ service up to the last customer, even when the office business hours end (1.75).

The analysis of the results from the point of view of the type of disability is summarized in Table 2. Based on the analysis by the nonparametric ANOVA Kruskal-Wallis test, there were statistically significant differences $(\alpha=0.01)$ for variables J1, J16 and J20. On average, the rate slightly better the level of service for people with a mild degree of disability $(-1.49)$ compared to a moderate level $(-1.56)$ or people with a significant degree of disability $(-1.57)$. The results confirm, but only to a very limited extent, the H2 hypothesis that the degree of disability affects the level of disabled customer service. For most variables, no such relationship was observed.

According to the Cramér's V correlation coefficient at the level of statistical significance $\alpha=0.01$, correlations occur between variables J16 and J20 and the degree of disability. Their values oscillate around 0.06 , so they are at a very low level, but they are statistically significant.

The phenomenon is understandable, because the higher the level of disability, the easier it is for a person to notice any service shortcomings, although such shortcomings are not always and only those directly related to the difficulties of the disabled person's functioning in public space. This is obvious in the example of one of the statistically significant variables regarding the polite and friendly attitude of officials to customers. For people with mild disability, the rating is -1.29 ; those who have a moderate level of disability, rate it as -1.44 ; while the rating by people with a significant degree of disability is -1.62 . This proves that the degree of disability affects in some way the perception of the world and the behavior of other people towards us and is not always directly related to disability issues.

Table 2 also presents an assessment of the quality of customer service broken down by disability types. For the dependence analysis, the nonparametric ANOVA Kruskal-Wallis test was used, which is fulfilled at the highest significance level of $\alpha=0.001$ for many variables applied in the subjects tested: J1, J2, J7, J8, J10, J11, J13, J16, J17, J18, J27, J28, J29, J30. This means that these variables differ in a statistically significant manner depending on the type of disability of the respondents.

The obtained research results confirm the $\mathrm{H} 3$ hypothesis that the type of disability has a significant impact on the perceived level of disabled customer service. The worst quality of customer service is assessed in the surveyed city offices by people who have reduced social performance (-1.7). These are people with nervous or emotional disorders who are easily getting anxious and therefore negatively perceive many aspects of the level of service in offices. This can be seen even in the case of the variable regarding office opening hours, where there are no other logical reasons why people with reduced efficiency of social functioning assess it as the worst. Such customers rate the office opening hours as very bad (score -2.36 ), while, conversely, people with reduced sensory performance rate the same variable at the level of -1.89 .

The case of the variable concerning the willingness to help customers by officials is similar. Again, it seems that this help is more needed for people with reduced mobility or reduced communication skills. Meanwhile, people with reduced social performance again rated officials as the worst, i.e., as 1.97; while the same problem is assessed by people with reduced mobility at the level of -1.57 ; while by people with reduced communication efficiency at the level of -1.52 . 
Table 2. Assessment of the quality of customer service broken down by disability levels and disability types.

\begin{tabular}{|c|c|c|c|c|c|c|c|c|}
\hline \multirow[b]{2}{*}{ Variables } & \multicolumn{3}{|c|}{ Disability Level } & \multicolumn{5}{|c|}{ Disability Type } \\
\hline & $\begin{array}{l}\text { Significant } \\
(N=400)\end{array}$ & $\begin{array}{l}\text { Moderate } \\
(\mathrm{N}=1057)\end{array}$ & $\begin{array}{c}\text { Low } \\
(\mathrm{N}=1384)\end{array}$ & $\begin{array}{c}\text { Reduced } \\
\text { Sensory } \\
\text { Performance } \\
(\mathrm{N}=644)\end{array}$ & $\begin{array}{c}\text { Reduced } \\
\text { Intellectual } \\
\text { Performance } \\
(\mathbf{N}=\mathbf{1 8 2})\end{array}$ & $\begin{array}{l}\text { Reduced } \\
\text { Efficiency of } \\
\text { Social } \\
\text { Functioning } \\
(\mathrm{N}=399)\end{array}$ & $\begin{array}{c}\text { Reduced } \\
\text { Communication } \\
\text { Efficiency } \\
(\mathrm{N}=444)\end{array}$ & $\begin{array}{c}\text { Reduced } \\
\text { Mobility } \\
(\mathbf{N}=1153)\end{array}$ \\
\hline $\mathrm{J} 1$ & -1.18 & -1.01 & -0.97 & -0.94 & -1.23 & -1.16 & -1.12 & -0.92 \\
\hline $\mathrm{J} 2$ & -0.89 & -0.83 & -0.74 & -0.63 & -1.16 & -1.05 & -0.86 & -0.72 \\
\hline $\mathrm{J} 3$ & -1.58 & -1.41 & -1.34 & -1.38 & -1.51 & -1.50 & -1.37 & -1.35 \\
\hline $\mathrm{J} 4$ & -1.26 & -1.46 & -1.37 & -1.32 & -1.40 & -1.41 & -1.26 & -1.46 \\
\hline $\mathrm{J} 5$ & -1.08 & -0.82 & -0.79 & -0.88 & -1.31 & -0.87 & -0.75 & -0.78 \\
\hline J6 & -1.66 & -1.53 & -1.55 & -1.45 & -1.57 & -1.69 & -1.46 & -1.62 \\
\hline $\mathrm{J} 7$ & -1.99 & -2.05 & -2.07 & -1.89 & -1.95 & -2.36 & -1.81 & -2.14 \\
\hline $\mathrm{J} 8$ & -1.84 & -1.93 & -1.85 & -1.69 & -1.69 & -2.08 & -1.97 & -1.89 \\
\hline J9 & -1.78 & -1.72 & -1.61 & -1.59 & -1.66 & -1.83 & -1.64 & -1.67 \\
\hline J10 & -1.71 & -1.68 & -1.64 & -1.61 & -1.68 & -1.92 & -1.61 & -1.63 \\
\hline J11 & -1.59 & -1.68 & -1.62 & -1.54 & -1.61 & -1.83 & -1.54 & -1.65 \\
\hline $\mathrm{J} 12$ & -1.38 & -1.44 & -1.44 & -1.33 & -1.42 & -1.55 & -1.41 & -1.43 \\
\hline $\mathrm{J} 13$ & -1.67 & -1.71 & -1.63 & -1.65 & -1.81 & -1.97 & -1.52 & -1.57 \\
\hline $\mathrm{J} 14$ & -1.96 & -1.95 & -1.88 & -1.76 & -1.87 & -2.06 & -1.82 & -1.98 \\
\hline J15 & -1.77 & -1.88 & -1.79 & -1.64 & -1.78 & -2.06 & -1.69 & -1.89 \\
\hline $\mathrm{J} 16$ & -1.70 & -1.72 & -1.50 & -1.34 & -1.79 & -1.70 & -1.55 & -1.71 \\
\hline J17 & -1.39 & -1.41 & -1.26 & -1.04 & -1.50 & -1.63 & -1.16 & -1.41 \\
\hline J18 & -1.36 & -1.35 & -1.29 & -1.14 & -1.57 & -1.50 & -1.16 & -1.37 \\
\hline J19 & -1.31 & -1.29 & -1.22 & -1.12 & -1.50 & -1.46 & -1.11 & -1.28 \\
\hline $\mathrm{J} 20$ & -1.62 & -1.44 & -1.29 & -1.30 & -1.53 & -1.61 & -1.28 & -1.38 \\
\hline $\mathrm{J} 21$ & -1.28 & -1.29 & -1.24 & -1.13 & -1.43 & -1.38 & -1.24 & -1.26 \\
\hline $\mathrm{J} 22$ & -1.43 & -1.42 & -1.40 & -1.35 & -1.38 & -1.50 & -1.30 & -1.44 \\
\hline $\mathrm{J} 23$ & -1.78 & -1.81 & -1.70 & -1.69 & -1.79 & -1.75 & -1.77 & -1.74 \\
\hline $\mathrm{J} 24$ & -1.66 & -1.71 & -1.57 & -1.48 & -1.79 & -1.74 & -1.54 & -1.68 \\
\hline $\mathrm{J} 25$ & -1.12 & -1.03 & -1.06 & -0.93 & -1.08 & -1.22 & -1.06 & -1.07 \\
\hline $\mathrm{J} 26$ & -1.42 & -1.39 & -1.33 & -1.20 & -1.38 & -1.54 & -1.32 & -1.41 \\
\hline $\mathrm{J} 27$ & -2.14 & -1.98 & -1.98 & -1.80 & -1.77 & -2.12 & -1.87 & -2.16 \\
\hline $\mathrm{J} 28$ & -1.82 & -1.82 & -1.82 & -1.47 & -1.65 & -2.21 & -1.80 & -1.88 \\
\hline $\mathrm{J} 29$ & -1.94 & -2.13 & -1.97 & -1.77 & -2.00 & -2.20 & -1.85 & -2.16 \\
\hline $\mathrm{J} 30$ & -1.84 & -1.91 & -1.77 & -1.53 & -1.66 & -2.08 & -1.83 & -1.93 \\
\hline J31 & -1.63 & -1.47 & -1.62 & -1.36 & -1.52 & -1.73 & -1.50 & -1.63 \\
\hline $\mathrm{J} 32$ & -1.48 & -1.51 & -1.43 & -1.36 & -1.43 & -1.57 & -1.41 & -1.49 \\
\hline Average & -1.57 & -1.56 & -1.49 & -1.38 & -1.58 & -1.70 & -1.46 & -1.55 \\
\hline
\end{tabular}

Source: own work.

Most of the variables related to the level of customer service are correlated with the type of disability, according to the Cramér's V correlation coefficient at the significance level $\alpha=0.01$. The correlations fall in the range between 0.06 and 0.08 . 
In the next stage, researchers decided to check whether the education of surveyed people with disabilities affects the results of customer satisfaction surveys on the services provided by the municipal office (Table 3). Research shows that education has very little effect on research results. The $\mathrm{H} 4$ hypothesis that the education of a disabled person has a statistically significant impact on the perceived level of quality of disabled customer service has not been confirmed. Based on the nonparametric ANOVA Kruskal-Wallis test, statistically significant relationships were found at the significance level $\alpha=0.05$ for three variables: J6, J9 and J24. For these variables, it is not possible to determine any trend as to people with what kind of education perceive the examined variables better. For example, the timeliness of the service is rated best by people with elementary education $(-1.45)$ and the worst by people with higher education $(-1.61)$; the variable of quick resolution of customer matters is rated highest by people with higher education $(-1.61)$, and the worst by people with secondary education $(-1.75)$.

Table 3. Assessment of the quality level of disabled customer service by municipal offices broken down into the education of disabled people and age of disabled people.

\begin{tabular}{|c|c|c|c|c|c|c|c|c|}
\hline \multirow[b]{2}{*}{ Variables } & \multicolumn{3}{|c|}{ Education Level } & \multicolumn{5}{|c|}{ Age Range } \\
\hline & $\begin{array}{l}\text { Elementary } \\
(\mathrm{N}=570)\end{array}$ & $\begin{array}{l}\text { Secondary } \\
(\mathrm{N}=1591)\end{array}$ & $\begin{array}{l}\text { Higher } \\
(\mathrm{N}=651)\end{array}$ & $\begin{array}{l}\text { Below } 20 \\
\text { Years Old } \\
(\mathrm{N}=225)\end{array}$ & $\begin{array}{c}20-29 \\
\text { Years Old } \\
(\mathrm{N}=763)\end{array}$ & $\begin{array}{c}30-39 \\
\text { Years Old } \\
(\mathrm{N}=758)\end{array}$ & $\begin{array}{c}40-49 \\
\text { Years Old } \\
(N=641)\end{array}$ & $\begin{array}{c}50 \text { Years Old } \\
\text { and Over } \\
(\mathrm{N}=459)\end{array}$ \\
\hline $\mathrm{J} 1$ & -1.10 & -1.01 & -1.01 & -1.11 & -0.84 & -0.96 & -1.20 & -1.08 \\
\hline $\mathrm{J} 2$ & -0.82 & -0.76 & -0.83 & -0.60 & -0.75 & -0.78 & -0.79 & -0.96 \\
\hline $\mathrm{J} 3$ & -1.38 & -1.45 & -1.27 & -1.11 & -1.27 & -1.33 & -1.55 & -1.66 \\
\hline $\mathrm{J} 4$ & -1.39 & -1.34 & -1.41 & -1.12 & -1.26 & -1.30 & -1.56 & -1.64 \\
\hline $\mathrm{J} 5$ & -0.92 & -0.87 & -0.76 & -0.92 & -0.62 & -0.82 & -0.86 & -1.18 \\
\hline J6 & -1.45 & -1.62 & -1.59 & -1.30 & -1.59 & -1.56 & -1.68 & -1.47 \\
\hline $\mathrm{J} 7$ & -1.98 & -2.09 & -2.06 & -2.12 & -2.08 & -2.09 & -1.95 & -2.04 \\
\hline J8 & -1.84 & -1.91 & -1.91 & -1.65 & -1.85 & -1.83 & -2.05 & -1.88 \\
\hline J9 & -1.62 & -1.75 & -1.61 & -1.49 & -1.65 & -1.67 & -1.73 & -1.71 \\
\hline $\mathrm{J} 10$ & -1.59 & -1.70 & -1.69 & -1.35 & -1.64 & -1.60 & -1.83 & -1.75 \\
\hline J11 & -1.66 & -1.64 & -1.62 & -1.49 & -1.64 & -1.57 & -1.68 & -1.76 \\
\hline $\mathrm{J} 12$ & -1.50 & -1.42 & -1.45 & -1.35 & -1.39 & -1.40 & -1.53 & -1.44 \\
\hline $\mathrm{J} 13$ & -1.67 & -1.68 & -1.68 & -1.54 & -1.59 & -1.62 & -1.86 & -1.65 \\
\hline J14 & -1.91 & -1.90 & -1.87 & -1.80 & -1.83 & -1.75 & -2.11 & -2.10 \\
\hline J15 & -1.81 & -1.83 & -1.80 & -1.66 & -1.75 & -1.68 & -1.97 & -2.05 \\
\hline $\mathrm{J} 16$ & -1.69 & -1.54 & -1.62 & -1.49 & -1.48 & -1.55 & -1.72 & -1.83 \\
\hline J17 & -1.37 & -1.33 & -1.32 & -1.12 & -1.37 & -1.26 & -1.41 & -1.41 \\
\hline J18 & -1.31 & -1.37 & -1.27 & -1.08 & -1.36 & -1.26 & -1.33 & -1.47 \\
\hline J19 & -1.25 & -1.28 & -1.28 & -1.17 & -1.26 & -1.19 & -1.29 & -1.36 \\
\hline $\mathrm{J} 20$ & -1.36 & -1.41 & -1.43 & -1.12 & -1.50 & -1.31 & -1.47 & -1.39 \\
\hline $\mathrm{J} 21$ & -1.25 & -1.28 & -1.30 & -1.06 & -1.33 & -1.20 & -1.32 & -1.30 \\
\hline $\mathrm{J} 22$ & -1.49 & -1.41 & -1.39 & -1.29 & -1.34 & -1.44 & -1.40 & -1.58 \\
\hline $\mathrm{J} 23$ & -1.73 & -1.79 & -1.70 & -1.61 & -1.78 & -1.65 & -1.87 & -1.77 \\
\hline $\mathrm{J} 24$ & -1.62 & -1.70 & -1.51 & -1.51 & -1.65 & -1.54 & -1.68 & -1.75 \\
\hline $\mathrm{J} 25$ & -1.04 & -1.07 & -1.10 & -1.06 & -1.07 & -1.08 & -1.01 & -1.05 \\
\hline $\mathrm{J} 26$ & -1.38 & -1.38 & -1.34 & -1.14 & -1.36 & -1.34 & -1.41 & -1.48 \\
\hline $\mathrm{J} 27$ & -1.91 & -2.05 & -2.04 & -1.48 & -1.99 & -2.06 & -2.09 & -2.07 \\
\hline
\end{tabular}


Table 3. Cont

\begin{tabular}{|c|c|c|c|c|c|c|c|c|}
\hline \multirow[b]{2}{*}{ Variables } & \multicolumn{3}{|c|}{ Education Level } & \multicolumn{5}{|c|}{ Age Range } \\
\hline & $\begin{array}{l}\text { Elementary } \\
(\mathrm{N}=570)\end{array}$ & $\begin{array}{l}\text { Secondary } \\
(N=1591)\end{array}$ & $\begin{array}{l}\text { Higher } \\
(\mathrm{N}=651)\end{array}$ & $\begin{array}{l}\text { Below } 20 \\
\text { Years Old } \\
(\mathrm{N}=225)\end{array}$ & $\begin{array}{c}20-29 \\
\text { Years Old } \\
(N=763)\end{array}$ & $\begin{array}{c}30-39 \\
\text { Years Old } \\
(N=758)\end{array}$ & $\begin{array}{c}40-49 \\
\text { Years Old } \\
(N=641)\end{array}$ & $\begin{array}{c}50 \text { Years Old } \\
\text { and Over } \\
(\mathrm{N}=459)\end{array}$ \\
\hline $\mathrm{J} 28$ & -1.86 & -1.78 & -1.85 & -1.82 & -1.82 & -1.78 & -1.79 & -1.91 \\
\hline $\mathrm{J} 29$ & -2.03 & -2.00 & -2.01 & -1.75 & -2.00 & -1.99 & -2.11 & -2.17 \\
\hline $\mathrm{J} 30$ & -1.80 & -1.84 & -1.82 & -1.54 & -1.77 & -1.86 & -1.89 & -1.99 \\
\hline J31 & -1.57 & -1.59 & -1.58 & -1.44 & -1.46 & -1.61 & -1.58 & -1.69 \\
\hline $\mathrm{J} 32$ & -1.46 & -1.50 & -1.45 & -1.42 & -1.44 & -1.45 & -1.50 & -1.52 \\
\hline Average & -1.52 & -1.54 & -1.52 & -1.37 & -1.49 & -1.49 & -1.60 & -1.63 \\
\hline
\end{tabular}

Table 4 also summarizes the assessment of disabled customer service levels by municipal offices from the perspective of the age of the disabled person. The data shows that the quality of services provided by the office is best assessed by young people, while with age, criticism in this area increases. Respectively, people under the age of 20 assess the quality of services in offices as -1.37; those in the range of 20-39 assign it the rating of -1.49 ; people aged 40-49 assess the discussed issue at the level of -1.6 ; while disabled people aged 50 and over assess the quality level as -1.63 .

The analyzes presented in the paper confirmed the $\mathrm{H} 5$ hypothesis that the age of the disabled person affects the assessment of the perceived level of service quality.

The nonparametric ANOVA Kruskal-Wallis test confirmed the existence of statistically significant relationships (found at the highest significance level $\alpha=0.001$ ) among such variables as J3, J4, J5, J14, J27.

For most of the variables studied, negative Cramér's V correlations can be observed between the age of the disabled people surveyed and most of the variables studied. These correlations are statistically significant at the level of $\alpha=0.01$ but have a very small value (from 0.05 to 0.08 ).

ANOVA Kruskal-Wallis analysis showed that the assessment of a given office compared to others is a variable that strongly differentiates the level of disabled customer service in a given office. At the level of statistical significance $\alpha=0.001$, there are differences among all variables except J3, J23, J26, J27 and J29. The higher the office's rating compared to others, the higher the disabled clients rate it. People who believe that the surveyed service in one office is much worse than in other offices rated it at -2.46 ; people claiming that it is not much worse, rated it at the level of -1.96 , while people who think that the service is much better, rate the given office at the level of -1.31 (Table 4). It is again obvious that previous experience and knowledge of good service affects customer assessments. When a person comes across facilities where service is exemplary, then they assess the average service in other places as much worse. Conversely, if a person has never encountered good customer service, they tend to treat even poor customer service as something normal, which though not the best is typical.

Cramér's V correlation coefficients for the relationship between the examined variables and the office assessment against other institutions are positive and range from 0.08 to 0.17 . They are statistically significant at a high level of $\alpha=0.001$.

The results concerning the relationship between the variables examined regarding the quality of customer service and the assessment of the office against other institutions used by the examined persons confirm the H6 hypothesis-the assessment of a given office compared to other has an impact on the perceived quality level of services provided by a given municipal office for people with disabilities. When people with disability have contact with other municipal offices with a better level of services, they tend to worst perceive the level of services in the particular municipal office. 
In the next stage of the research, 32 individual variables were analyzed in terms of the quality level of disabled customer service by municipal offices from the point of view of the cities studied. The results of the tests for individual variables are summarized in Tables 5-8, while Figure 2 presents the aggregate results of the quality of service for individual cities studied.

As results from the conducted research show, issues concerning the quality level of disabled customer service were rated as good in cities such as:

- Mikołów (-0.09);

- Knurów $(-0.14)$;

- Żywiec (-0.27 rating);

- $\quad$ Orzesze $(-0.81)$;

- Rydułtowy $(-0.87)$,

Table 4. Assessment of the quality level of disabled customer service from the point of view of assessing a given office against other public administration institutions.

\begin{tabular}{|c|c|c|c|c|c|c|}
\hline \multirow[b]{2}{*}{ Variables } & \multicolumn{6}{|c|}{ Assessment of the Office Against Other Offices } \\
\hline & $\begin{array}{l}\text { Significantly Worse } \\
\qquad(\mathrm{N}=46)\end{array}$ & $\begin{array}{l}\text { Worse } \\
(\mathrm{N}=78)\end{array}$ & $\begin{array}{l}\text { Slightly Worse } \\
\quad(\mathrm{N}=244)\end{array}$ & $\begin{array}{l}\text { Slightly Better } \\
\quad(\mathbf{N}=1752)\end{array}$ & $\begin{array}{c}\text { Better } \\
(\mathrm{N}=527)\end{array}$ & $\begin{array}{l}\text { Significantly Better } \\
\quad(\mathrm{N}=164)\end{array}$ \\
\hline $\mathrm{J} 1$ & -1.85 & -1.69 & -1.15 & -0.99 & -0.94 & -0.71 \\
\hline $\mathrm{J} 2$ & -1.35 & -1.05 & -1.15 & -0.77 & -0.65 & -0.57 \\
\hline $\mathrm{J} 3$ & -2.04 & -1.73 & -1.57 & -1.38 & -1.34 & -1.03 \\
\hline $\mathrm{J} 4$ & -2.46 & -1.58 & -1.84 & -1.37 & -1.20 & -1.35 \\
\hline $\mathrm{J} 5$ & -2.20 & -1.88 & -1.21 & -0.85 & -0.55 & -0.32 \\
\hline J6 & -2.78 & -2.00 & -2.11 & -1.57 & -1.20 & -1.43 \\
\hline $\mathrm{J} 7$ & -2.85 & -2.46 & -2.21 & -2.10 & -1.89 & -1.54 \\
\hline $\mathrm{J} 8$ & -2.46 & -2.45 & -2.25 & -1.94 & -1.54 & -1.59 \\
\hline J9 & -2.26 & -2.22 & -2.20 & -1.69 & -1.30 & -1.46 \\
\hline $\mathrm{J} 10$ & -2.85 & -1.91 & -1.98 & -1.65 & -1.43 & -1.64 \\
\hline J11 & -2.50 & -1.92 & -2.06 & -1.65 & -1.31 & -1.55 \\
\hline J12 & -2.09 & -1.67 & -1.71 & -1.46 & -1.21 & -1.30 \\
\hline $\mathrm{J} 13$ & -2.72 & -2.14 & -2.28 & -1.68 & -1.32 & -1.40 \\
\hline J14 & -2.93 & -2.05 & -2.50 & -1.95 & -1.58 & -1.66 \\
\hline J15 & -2.85 & -2.31 & -2.29 & -1.87 & -1.52 & -1.47 \\
\hline J16 & -2.37 & -2.08 & -2.30 & -1.62 & -1.31 & -1.17 \\
\hline J17 & -2.61 & -1.76 & -1.95 & -1.29 & -1.04 & -1.37 \\
\hline $\mathrm{J} 18$ & -2.02 & -1.86 & -1.84 & -1.29 & -1.05 & -1.21 \\
\hline J19 & -2.50 & -1.59 & -1.86 & -1.21 & -1.03 & -1.08 \\
\hline $\mathrm{J} 20$ & -2.57 & -2.09 & -1.87 & -1.40 & -1.02 & -1.07 \\
\hline $\mathrm{J} 21$ & -2.39 & -1.73 & -1.68 & -1.26 & -0.99 & -1.15 \\
\hline $\mathrm{J} 22$ & -2.59 & -2.08 & -1.81 & -1.43 & -1.02 & -1.21 \\
\hline $\mathrm{J} 23$ & -2.46 & -2.24 & -2.25 & -1.74 & -1.50 & -1.51 \\
\hline $\mathrm{J} 24$ & -2.72 & -1.86 & -2.02 & -1.64 & -1.36 & -1.40 \\
\hline $\mathrm{J} 25$ & -2.02 & -1.42 & -1.63 & -1.05 & -0.80 & -0.98 \\
\hline $\mathrm{J} 26$ & -2.22 & -1.53 & -1.75 & -1.39 & -1.13 & -1.07 \\
\hline $\mathrm{J} 27$ & -2.33 & -2.35 & -2.31 & -2.06 & -1.71 & -1.85 \\
\hline $\mathrm{J} 28$ & -2.63 & -1.81 & -2.18 & -1.82 & -1.62 & -1.64 \\
\hline
\end{tabular}


Table 4. Cont.

\begin{tabular}{|c|c|c|c|c|c|c|}
\hline \multirow[b]{2}{*}{ Variables } & \multicolumn{6}{|c|}{ Assessment of the Office Against Other Offices } \\
\hline & $\begin{array}{l}\text { Significantly Worse } \\
\qquad(\mathrm{N}=46)\end{array}$ & $\begin{array}{c}\text { Worse } \\
(N=78)\end{array}$ & $\begin{array}{l}\text { Slightly Worse } \\
\text { (N = 244) }\end{array}$ & $\begin{array}{l}\text { Slightly Better } \\
\text { ( } \mathbf{N}=1752)\end{array}$ & $\begin{array}{c}\text { Better } \\
(N=527)\end{array}$ & $\begin{array}{l}\text { Significantly Better } \\
(N=164)\end{array}$ \\
\hline J29 & -2.37 & -2.36 & -2.48 & -2.04 & -1.72 & -2.00 \\
\hline $\mathrm{J} 30$ & -2.41 & -2.13 & -2.31 & -1.82 & -1.69 & -1.53 \\
\hline $\mathrm{J} 31$ & -2.54 & -2.03 & -1.94 & -1.53 & -1.42 & -1.38 \\
\hline $\mathrm{J} 32$ & -2.46 & -1.92 & -2.04 & -1.38 & -1.30 & -1.40 \\
\hline Average & -2.42 & -1.93 & -1.96 & -1.53 & -1.27 & -1.31 \\
\hline
\end{tabular}

Source: own work.

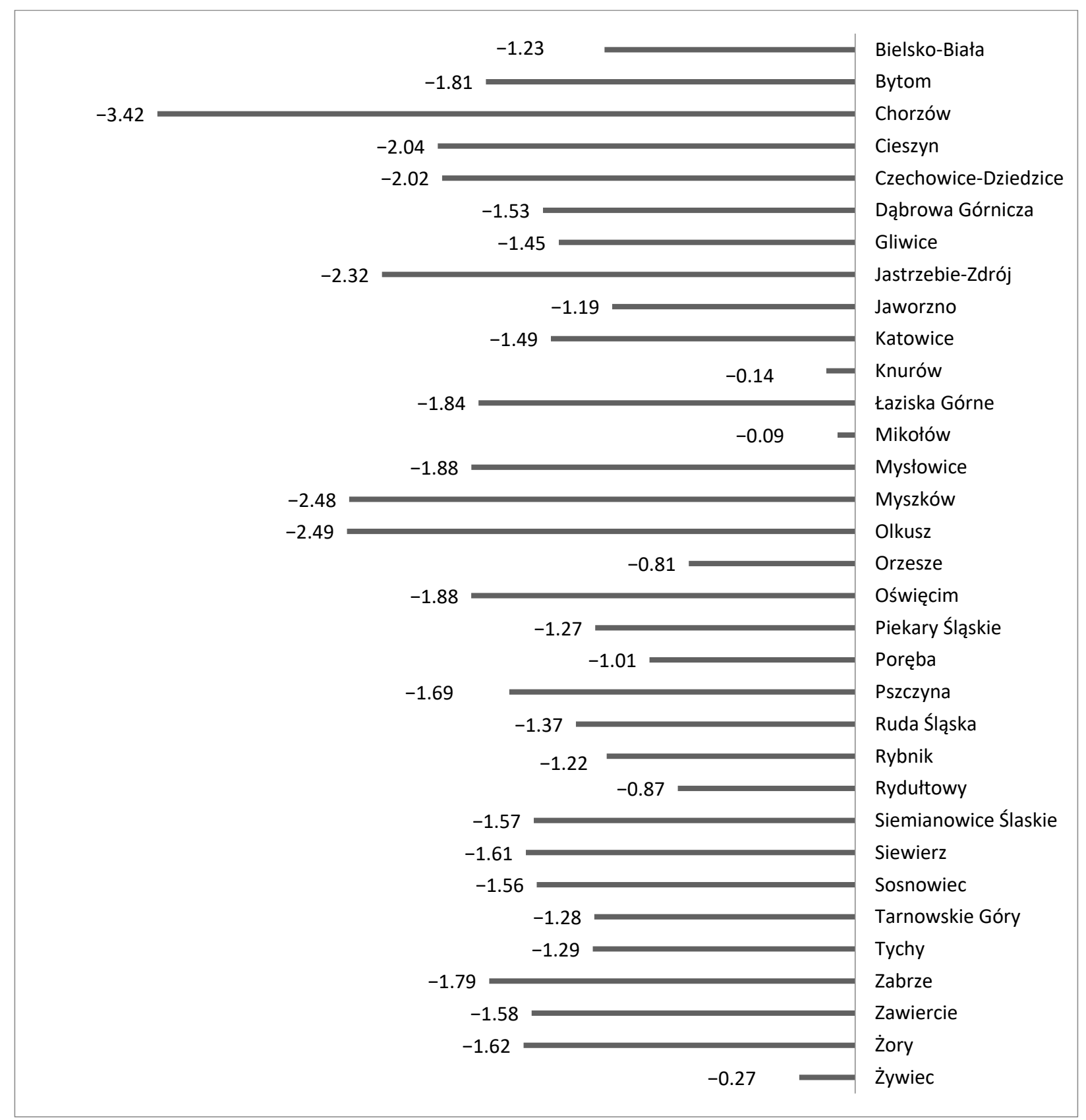

Figure 2. The level of customer with a disability service in the studied municipal offices in different cities. Source: own work. 
Research shows that city office located in small cities were rated best. Most likely, the cozy atmosphere prevailing in these offices and the personal relations between officials and a given disabled person cause ratings to be high in such cities.

At a very poor level, the quality of services provided by municipal offices was assessed by disabled people in the following cities:

- Chorzów (-3.42);

- Olkusz (-2.49);

- Myszków (-2.48);

- Jastrzębie-Zdrój (-2.32);

- Cieszyn (-2.04);

- $\quad$ Czechowice-Dziedzice (-2.02).

Table 5. The level of service quality by city-variables J1-J8.

\begin{tabular}{|c|c|c|c|c|c|c|c|c|}
\hline & J1: & J2: & J3: & J4: & J5: & J6: & J7: & J8: \\
\hline Bielsko-Biała & -0.69 & -0.59 & -1.07 & -1.00 & -0.57 & -1.08 & -2.04 & -1.37 \\
\hline Bytom & -1.59 & -1.18 & -1.51 & -1.71 & -1.40 & -1.71 & -2.08 & -2.30 \\
\hline Chorzów & -2.33 & -2.03 & -2.47 & -2.63 & -2.97 & -3.00 & -4.13 & -3.73 \\
\hline Cieszyn & -1.20 & -1.25 & -2.35 & -1.20 & -1.24 & -1.24 & -0.75 & -1.30 \\
\hline $\begin{array}{l}\text { Czechowice- } \\
\text { Dziedzice }\end{array}$ & -1.28 & -0.82 & -1.14 & -1.39 & -0.82 & -1.71 & -2.63 & -2.66 \\
\hline Dąbrowa-Górnicza & -1.33 & -1.13 & -2.19 & -1.70 & -0.50 & -1.09 & -1.94 & -1.90 \\
\hline Gliwice & -0.60 & -0.54 & -0.67 & -1.23 & -0.50 & -2.04 & -2.11 & -2.41 \\
\hline Jastrzebie-Zdrój & -0.95 & -0.48 & -0.95 & -2.42 & -0.37 & -2.65 & -3.23 & -3.02 \\
\hline Jaworzno & -1.67 & 0.48 & -0.20 & -0.51 & -0.41 & -1.47 & -1.53 & -1.61 \\
\hline Katowice & -0.95 & -1.06 & -1.35 & -1.49 & -1.02 & -1.45 & -1.95 & -1.59 \\
\hline Knurów & 1.13 & 2.23 & -3.20 & 0.63 & 2.20 & -1.23 & -4.23 & -1.20 \\
\hline Łaziska Górne & -1.70 & -1.43 & -1.47 & -1.73 & -1.45 & -1.72 & -1.85 & -1.77 \\
\hline Mikołów & 0.23 & 0.00 & -0.03 & 0.13 & -0.03 & 0.03 & 0.07 & -0.33 \\
\hline Mysłowice & -1.50 & -1.25 & -1.46 & -1.47 & -1.49 & -1.87 & -2.50 & -2.26 \\
\hline Myszków & -1.80 & -1.88 & -2.52 & -2.52 & -2.78 & -2.88 & -2.97 & -2.78 \\
\hline Olkusz & -2.20 & -1.93 & -2.33 & -2.43 & -2.87 & -2.67 & -2.70 & -2.47 \\
\hline Orzesze & -0.03 & 0.07 & -1.17 & -0.93 & -0.27 & -0.53 & -2.13 & -1.17 \\
\hline Oświęcim & -1.10 & -1.42 & -1.68 & -1.82 & -1.45 & -2.32 & -1.93 & -2.62 \\
\hline Piekary Śląskie & -0.40 & -0.57 & -3.40 & -2.63 & -0.17 & -0.57 & -2.27 & -1.27 \\
\hline Poręba & -1.43 & 0.00 & -1.30 & 0.00 & -2.93 & 0.00 & -2.33 & -1.93 \\
\hline Pszczyna & -1.28 & -1.13 & -1.30 & -1.44 & -1.18 & -1.64 & -2.00 & -2.22 \\
\hline Ruda Śląska & -1.08 & -0.82 & -1.15 & -0.82 & -0.33 & -1.22 & -2.33 & -1.61 \\
\hline Rybnik & -0.42 & -0.58 & -0.92 & -0.92 & -0.12 & -1.18 & -1.84 & -1.46 \\
\hline Rydułtowy & -0.63 & -0.20 & 0.17 & 0.00 & -0.23 & -1.33 & -0.73 & -1.93 \\
\hline $\begin{array}{l}\text { Siemianowice } \\
\text { Ślaskie }\end{array}$ & -1.50 & -0.17 & -1.57 & -2.07 & -1.10 & -1.60 & -0.37 & -1.50 \\
\hline Siewierz & -0.17 & -0.67 & -2.87 & -0.80 & -0.53 & -3.00 & -3.53 & -2.60 \\
\hline Sosnowiec & -1.01 & -0.90 & -1.97 & -1.11 & -1.13 & -1.89 & -1.79 & -1.31 \\
\hline Tarnowskie Góry & -0.96 & -0.60 & -1.59 & -1.23 & -0.48 & -1.17 & -2.33 & -1.25 \\
\hline Tychy & -0.63 & -0.35 & -0.51 & -0.89 & 0.11 & -1.62 & -1.22 & -2.07 \\
\hline Zabrze & -1.24 & -1.13 & -2.05 & -1.97 & -1.17 & -1.86 & -1.88 & -2.19 \\
\hline Zawiercie & -0.62 & -0.55 & -1.72 & -2.57 & -0.12 & -1.82 & -2.08 & -3.02 \\
\hline Żory & -0.83 & -0.03 & -1.27 & -2.07 & -0.87 & -1.67 & -4.23 & -2.13 \\
\hline Żywiec & 0.23 & 0.43 & -0.70 & -0.23 & 0.27 & -0.27 & -1.57 & -0.47 \\
\hline
\end{tabular}

Source: own work based on the survey results (B3C). 
Table 6. The level of service quality by city—variables J9-J16.

\begin{tabular}{|c|c|c|c|c|c|c|c|c|}
\hline & J9: & J10: & J11: & J12: & J13: & J14: & J15: & J16: \\
\hline Bielsko-Biała & -1.34 & -1.31 & -1.33 & -1.17 & -1.31 & -1.47 & -1.30 & -1.34 \\
\hline Bytom & -2.02 & -1.94 & -1.79 & -1.69 & -1.64 & -2.10 & -2.26 & -2.10 \\
\hline Chorzów & -3.33 & -3.27 & -3.80 & -3.40 & -3.43 & -3.97 & -3.77 & -3.60 \\
\hline Cieszyn & -1.40 & -1.50 & -1.36 & -1.47 & -1.45 & -2.80 & -2.90 & -2.47 \\
\hline $\begin{array}{l}\text { Czechowice- } \\
\text { Dziedzice }\end{array}$ & -2.40 & -2.27 & -2.23 & -2.07 & -2.12 & -2.09 & -2.11 & -2.29 \\
\hline $\begin{array}{l}\text { Daabrowa- } \\
\text { Górnicza }\end{array}$ & -1.39 & -1.71 & -1.51 & -1.38 & -1.41 & -1.50 & -1.43 & -1.52 \\
\hline Gliwice & -1.94 & -1.41 & -1.46 & -1.36 & -1.61 & -1.66 & -2.03 & -1.18 \\
\hline Jastrzebie-Zdrój & -3.02 & -2.95 & -2.73 & -1.93 & -2.48 & -2.67 & -2.00 & -1.92 \\
\hline Jaworzno & -1.52 & -1.58 & -1.53 & -1.42 & -1.62 & -1.24 & -1.14 & -1.03 \\
\hline Katowice & -1.49 & -1.43 & -1.55 & -1.42 & -1.64 & -1.89 & -1.84 & -1.69 \\
\hline Knurów & -0.97 & -0.57 & 0.30 & 0.60 & 1.17 & -2.83 & -2.10 & 1.17 \\
\hline Łaziska Górne & -1.90 & -1.87 & -1.70 & -1.78 & -1.78 & -2.17 & -2.13 & -2.10 \\
\hline Mikołów & 0.37 & -0.30 & 0.03 & 0.13 & -0.30 & -0.33 & -0.13 & -0.33 \\
\hline Mysłowice & -1.91 & -2.06 & -1.91 & -1.82 & -2.24 & -2.15 & -2.11 & -1.82 \\
\hline Myszków & -2.57 & -2.53 & -2.25 & -2.27 & -2.38 & -2.92 & -2.57 & -2.58 \\
\hline Olkusz & -2.20 & -2.33 & -2.33 & -2.13 & -2.30 & -2.30 & -2.30 & -2.27 \\
\hline Orzesze & -1.00 & -0.80 & -0.80 & -0.73 & -0.70 & -1.43 & -0.80 & -0.87 \\
\hline Oświęcim & -2.82 & -2.70 & -2.70 & -2.38 & -2.33 & -1.63 & -1.78 & -1.93 \\
\hline Piekary Śląskie & -0.73 & -1.10 & -1.30 & -1.17 & -1.07 & -1.67 & -1.37 & -1.23 \\
\hline Poręba & -1.83 & -1.77 & -1.57 & -1.60 & -2.23 & -0.97 & -2.00 & -1.70 \\
\hline Pszczyna & -1.76 & -1.78 & -1.93 & -1.69 & -1.80 & -2.57 & -2.20 & -1.80 \\
\hline Ruda Śląska & -1.37 & -1.58 & -1.43 & -1.10 & -1.56 & -1.77 & -1.62 & -1.14 \\
\hline Rybnik & -1.43 & -1.35 & -1.44 & -1.18 & -1.36 & -1.41 & -1.30 & -1.06 \\
\hline Rydułtowy & -1.50 & -1.60 & -1.53 & -0.87 & -1.57 & -0.70 & -1.40 & -0.77 \\
\hline $\begin{array}{l}\text { Siemianowice } \\
\text { Ślaskie }\end{array}$ & -1.93 & -1.37 & -2.03 & -1.43 & -2.03 & -2.00 & -2.03 & -1.57 \\
\hline Siewierz & -2.10 & -1.17 & -1.00 & -0.70 & -1.47 & -2.63 & -2.53 & -1.50 \\
\hline Sosnowiec & -1.51 & -1.62 & -1.56 & -1.44 & -1.76 & -2.12 & -1.84 & -2.22 \\
\hline Tarnowskie Góry & -1.22 & -1.23 & -1.38 & -0.83 & -1.21 & -1.68 & -1.49 & -1.48 \\
\hline Tychy & -1.84 & -1.78 & -1.72 & -1.42 & -1.41 & -1.56 & -1.38 & -1.56 \\
\hline Zabrze & -1.81 & -1.83 & -1.81 & -1.68 & -1.83 & -2.62 & -2.38 & -1.94 \\
\hline Zawiercie & -1.72 & -2.82 & -1.73 & -1.23 & -2.90 & -2.05 & -2.78 & -1.62 \\
\hline Żory & -1.50 & -1.50 & -1.53 & -1.20 & -1.63 & -2.87 & -2.40 & -2.37 \\
\hline Żywiec & -0.63 & -0.37 & -0.27 & -0.27 & -0.13 & -0.27 & 0.00 & -0.40 \\
\hline
\end{tabular}


Table 7. The level of service quality by city—variables J17-J24.

\begin{tabular}{|c|c|c|c|c|c|c|c|c|}
\hline & J17: & J18: & J19: & J20: & J21: & J22: & J23: & J24: \\
\hline Bielsko-Biała & -1.10 & -1.00 & -0.79 & -1.19 & -1.03 & -1.22 & -1.21 & -1.25 \\
\hline Bytom & -1.52 & -1.40 & -1.07 & -1.43 & -1.63 & -1.64 & -2.08 & -1.74 \\
\hline Chorzów & -3.43 & -2.97 & -2.80 & -3.57 & -3.53 & -3.40 & -4.17 & -4.07 \\
\hline Cieszyn & -2.48 & -2.58 & -1.70 & -2.58 & -2.48 & -2.90 & -3.10 & -2.90 \\
\hline $\begin{array}{l}\text { Czechowice- } \\
\text { Dziedzice }\end{array}$ & -1.89 & -1.89 & -1.50 & -1.98 & -1.80 & -2.13 & -2.31 & -2.14 \\
\hline $\begin{array}{l}\text { Dąbrowa- } \\
\text { Górnicza }\end{array}$ & -1.36 & -1.28 & -1.23 & -1.10 & -1.04 & -1.22 & -1.63 & -1.50 \\
\hline Gliwice & -1.28 & -1.50 & -1.38 & -1.47 & -1.44 & -1.49 & -1.64 & -1.62 \\
\hline Jastrzebie-Zdrój & -2.97 & -2.40 & -1.98 & -2.40 & -2.27 & -2.00 & -3.23 & -2.77 \\
\hline Jaworzno & -1.57 & -0.98 & -0.39 & -1.43 & -1.06 & -0.80 & -1.58 & -1.28 \\
\hline Katowice & -1.58 & -1.43 & -1.41 & -1.60 & -1.18 & -1.25 & -1.62 & -1.56 \\
\hline Knurów & 1.53 & 0.57 & -0.33 & -0.73 & 0.47 & 0.27 & -1.53 & -2.00 \\
\hline Łaziska Górne & -2.03 & -1.75 & -1.88 & -2.07 & -2.08 & -1.78 & -1.83 & -1.70 \\
\hline Mikołów & 0.10 & 0.03 & -0.10 & 0.00 & -0.23 & 0.10 & 0.07 & -0.40 \\
\hline Mysłowice & -1.59 & -1.47 & -1.41 & -1.64 & -1.45 & -1.85 & -1.65 & -1.99 \\
\hline Myszków & -2.07 & -2.03 & -2.25 & -2.18 & -2.17 & -2.27 & -2.40 & -2.20 \\
\hline Olkusz & -2.17 & -2.13 & -2.27 & -2.40 & -2.53 & -2.57 & -3.03 & -2.90 \\
\hline Orzesze & -0.27 & -0.30 & -0.33 & -0.53 & -0.37 & -0.93 & -1.30 & -0.90 \\
\hline Oświęcim & -1.28 & -1.60 & -1.17 & -1.63 & -1.85 & -1.57 & -2.90 & -2.38 \\
\hline Piekary Śląskie & -0.43 & -0.57 & -0.80 & -0.93 & -0.80 & -0.83 & -1.83 & -0.77 \\
\hline Poręba & -0.63 & -2.80 & -1.20 & -0.47 & 0.00 & -2.13 & 0.00 & -1.40 \\
\hline Pszczyna & -1.39 & -1.68 & -1.53 & -1.58 & -1.63 & -1.80 & -1.77 & -1.73 \\
\hline Ruda Śląska & -1.18 & -0.94 & -0.98 & -0.83 & -0.74 & -0.88 & -1.93 & -1.43 \\
\hline Rybnik & -1.11 & -1.03 & -0.89 & -1.12 & -1.23 & -1.32 & -1.58 & -1.42 \\
\hline Rydułtowy & -0.97 & -0.93 & -0.80 & -1.43 & -0.67 & -1.37 & -0.83 & -1.60 \\
\hline $\begin{array}{l}\text { Siemianowice } \\
\text { Ślaskie }\end{array}$ & -1.43 & -1.87 & -2.03 & -1.40 & -0.97 & -1.50 & -2.13 & -1.80 \\
\hline Siewierz & -1.07 & -1.10 & -0.87 & -1.20 & -0.80 & -0.77 & -0.90 & -0.97 \\
\hline Sosnowiec & -1.03 & -0.97 & -2.00 & -1.11 & -1.59 & -0.97 & -1.98 & -1.38 \\
\hline Tarnowskie Góry & -0.80 & -0.98 & -1.08 & -1.03 & -0.82 & -1.41 & -1.84 & -1.46 \\
\hline Tychy & -1.03 & -1.41 & -1.34 & -1.34 & -1.12 & -1.22 & -1.52 & -1.58 \\
\hline Zabrze & -1.57 & -1.59 & -1.38 & -1.38 & -1.29 & -1.65 & -1.69 & -1.82 \\
\hline Zawiercie & -0.45 & -0.22 & -0.50 & -1.10 & -1.87 & -2.40 & -2.88 & -1.70 \\
\hline Żory & -1.20 & -1.10 & -1.33 & -1.13 & -1.00 & -1.40 & -0.93 & -1.27 \\
\hline Żywiec & 0.00 & -0.03 & -0.03 & -0.13 & -0.53 & -0.10 & -0.93 & -0.47 \\
\hline
\end{tabular}


Table 8. The level of service quality by city—variables J25-J32.

\begin{tabular}{|c|c|c|c|c|c|c|c|c|}
\hline & J25: & J26: & J27: & J28: & J29: & J30: & J31: & J32: \\
\hline Bielsko-Biała & -0.76 & -0.89 & -1.69 & -1.71 & -1.62 & -1.83 & -1.57 & -1.43 \\
\hline Bytom & -1.49 & -1.68 & -2.34 & -2.76 & -2.33 & -2.20 & -2.06 & -1.47 \\
\hline Chorzów & -3.03 & -3.20 & -4.17 & -2.80 & -4.83 & -4.17 & -4.33 & -3.00 \\
\hline Cieszyn & -2.40 & -2.40 & -2.40 & -2.70 & -2.80 & -2.40 & -2.30 & -1.40 \\
\hline $\begin{array}{l}\text { Czechowice- } \\
\text { Dziedzice }\end{array}$ & -1.63 & -2.01 & -2.79 & -2.67 & -2.74 & -2.73 & -2.36 & -2.10 \\
\hline $\begin{array}{l}\text { Dąbrowa- } \\
\text { Górnicza }\end{array}$ & -1.49 & -1.84 & -1.87 & -2.12 & -2.13 & -2.04 & -1.50 & -1.91 \\
\hline Gliwice & -0.77 & -1.37 & -1.64 & -1.29 & -1.61 & -1.86 & -1.99 & -1.33 \\
\hline Jastrzebie-Zdrój & -2.40 & -1.88 & -3.07 & -2.67 & -3.38 & -2.12 & -2.42 & -2.43 \\
\hline Jaworzno & -1.43 & -0.83 & -1.40 & -1.88 & -1.51 & -1.42 & -1.11 & -1.38 \\
\hline Katowice & -1.02 & -1.48 & -1.81 & -1.80 & -2.06 & -1.71 & -1.12 & -1.26 \\
\hline Knurów & -0.30 & 1.47 & -5.17 & 1.97 & 1.70 & 1.90 & 1.60 & 0.97 \\
\hline Łaziska Górne & -1.60 & -1.98 & -2.02 & -2.12 & -1.98 & -1.80 & -1.83 & -2.00 \\
\hline Mikołów & -0.27 & 0.13 & 0.00 & -0.23 & -0.17 & -0.37 & -0.17 & -0.47 \\
\hline Mysłowice & -1.38 & -1.90 & -2.43 & -2.22 & -2.49 & -2.23 & -2.33 & -2.31 \\
\hline Myszków & -1.97 & -2.52 & -3.38 & -2.48 & -3.48 & -3.27 & -2.47 & -1.95 \\
\hline Olkusz & -2.57 & -2.67 & -2.77 & -2.73 & -2.83 & -2.77 & -2.80 & -2.73 \\
\hline Orzesze & -0.63 & -0.63 & -0.87 & -1.37 & -1.00 & -1.27 & -1.23 & -0.83 \\
\hline Oświęcim & -1.50 & -1.88 & -1.60 & -1.78 & -1.58 & -1.95 & -1.63 & -1.22 \\
\hline Piekary Śląskie & -0.70 & -1.07 & -2.07 & -1.97 & -2.20 & -1.90 & -1.17 & -1.80 \\
\hline Poręba & 0.00 & 0.00 & 0.00 & 0.00 & 0.00 & 0.00 & 0.00 & 0.00 \\
\hline Pszczyna & -1.09 & -1.36 & -2.19 & -1.58 & -2.18 & -1.91 & -1.62 & -1.43 \\
\hline Ruda Śląska & -1.17 & -1.44 & -1.85 & -2.18 & -2.34 & -2.20 & -1.33 & -1.40 \\
\hline Rybnik & -0.97 & -1.21 & -1.64 & -1.44 & -1.97 & -1.67 & -1.43 & -0.95 \\
\hline Rydułtowy & -0.53 & -1.07 & -1.67 & -0.23 & -0.70 & 0.20 & -0.23 & -0.13 \\
\hline $\begin{array}{l}\text { Siemianowice } \\
\text { Ślaskie }\end{array}$ & -1.07 & -1.23 & -1.43 & -1.63 & -1.50 & -1.97 & -2.10 & -2.03 \\
\hline Siewierz & -0.13 & -0.97 & -4.20 & -0.47 & -4.10 & -1.60 & -4.53 & -0.67 \\
\hline Sosnowiec & -0.69 & -1.59 & -1.62 & -1.72 & -1.74 & -1.84 & -2.30 & -2.17 \\
\hline Tarnowskie Góry & -0.28 & -0.89 & -1.88 & -1.47 & -1.93 & -1.86 & -1.66 & -1.36 \\
\hline Tychy & -0.66 & -1.28 & -1.63 & -1.69 & -1.66 & -1.61 & -0.91 & -1.28 \\
\hline Zabrze & -0.95 & -1.48 & -2.50 & -2.51 & -2.53 & -2.20 & -1.90 & -1.50 \\
\hline Zawiercie & -0.98 & -0.23 & -1.72 & -1.70 & -1.62 & -1.92 & 0.02 & -2.10 \\
\hline Żory & -0.27 & -1.30 & -3.00 & -2.60 & -2.90 & -1.43 & -2.00 & -1.00 \\
\hline Żywiec & -0.20 & -0.33 & -0.73 & 0.17 & -0.43 & -0.47 & 0.03 & 0.07 \\
\hline
\end{tabular}


The most important findings of our study based on the presented particular results are:

- The identification of the problematic areas in quality of services for peoples with disability in municipal offices: especially_problems with a fast response on e-mails, service to the last customer and also some problems with special services for customers with particular types of disability, for example, hearing impairment.

- We found out that disability type impacts the perceived level of quality. Each type of disability needs special, different approach because is linked with different impairments and different needs.

- We found that the level of education does not have statistically significant impact on the perceived quality of services. Regardless of the educational level, the people with disability perceive the quality of service level in municipal office similarly.

- We found out that the age of a person impacts on a statistically significant level on the perceived level of service quality in the municipal office. The older is the customer, the worse he will perceive service quality. The municipal office authorities should think about it in the process of service planning and assessment. They should pay special attention to people with disabilities older than 50 years because they have special needs and they do not always have appropriate knowledge about new technologies for example information technology.

\section{Discussion and Conclusions}

In recent years, there have been positive changes in public awareness related to the place and role of disabled people in modern society [44]. These changes make us feel optimistic and are a consequence of the growing social integration of people with disabilities $[20,21,26]$.

The process of sustainable urban planning and especially the process of building sustainable communities should lead to the fulfilment of all city dwellers. A very important group of those people are persons with disabilities. For disabled people who use public administration, two things are important: firstly, the issue of access to public space related to architectural barriers and their elimination, and secondly, the level of quality of service offered by public administration to people with disabilities (in particular, attention should be paid to the role of e-administration development from the perspective of people with disabilities) $[16,17,85]$.

Both access to public space and the appropriate level of services provided for people with disabilities are in line with the strategy of sustainable development and the concept of Society 5.0, i.e., "A human-oriented society in which economic progress that includes solutions to social issues is balanced by a system offering high integration of digital space and real." [1-3].

An important factor in the implementation of society 5.0 is the inclusion of excluded groups in terms of access to public areas [86]. In this context, a particularly important group are people with disabilities who require special attention, because the level of customer service that can be perceived as positive by typical customers is not always sufficient for people with disabilities. To date, the literature has dealt with the issue of examining the level of service for a disabled customer [87-91]; however, issues regarding the quality of customer service in municipal offices have not been discussed to a greater extent. The literature, especially the references concerning public management, emphasizes the importance of paying attention to people with disabilities by public administration $[45,92,93]$.

Based on the previous research, a moderate level of satisfaction was found in the disabled persons surveyed with the services rendered. Test results confirm other research conducted worldwide, for example, the results obtained by Habib et al. for Bangladesh [89].

In particular, in the context of this publication, organizational and information barriers are important, as they cause problems in communication between officials and people with disabilities [27-29]. The research shows that it is especially important to provide appropriate devices that allow communication with people with disabilities, such as, for example, with people with hearing or vision impairments. A very important factor is also 
the development of e-administration, which will improve the service of people with disabilities. Issues regarding the positive impact of e-administration used in disabled customer services have been raised in global studies [94-96]. Based on the research presented in this publication, we can say that this factor could allow providing better service to people with disabilities.

Ensuring better service for disabled customers will allow for better implementation of the concept of sustainable development and the idea of Society $5.0[5,6]$. As a result of the improved service for this group of customers, it is possible to improve their quality of life and facilitate their functioning in society. The research shows that the adjustment of the method of service to the type of disability is a particularly important issue, as this type has a statistically significant effect on the perceived quality of services. This is in line with the disability models discussed in the literature [27-29,38-40]. In particular, the focus should be on people with reduced efficiency of social functioning, who perceive the quality of service in the examined offices as particularly inadequate [84,97-100]. For this group of the disabled, the organizational and information barriers discussed are a particularly important factor [62-64] and the offices should make an effort to limit their impact, by such steps as training employees in terms of disabled customer service.

Good, high-quality service to excluded people, namely people with disabilities, is an important factor in implementing the concept of sustainable development and Society 5.0 in the city. In addition, paying attention to excluded people is important for implementing the currently popular concept of Smart City [101,102]. When we pay attention to the needs of those group of people, we can adjust the city to sustainable communities conception.

In the scope of testing the quality of customer service in city offices from the perspective of the disabled person, the results show that the best-rated variables include:

- well-groomed and neat appearance of officials ( -079 rating);

- renovated and attractive office building $(-0.84)$.

However, issues that cause problems in the disabled customer service process are:

- $\quad$ support for people with hearing impairments using a suitable device $(-2)$;

- speed of response to emails $(-1.91)$ - it is worth paying attention to this problem, especially in the context of using e-administration as a solution to the problem of inconvenient office opening hours;

- $\quad$ proper customer service the first time $(-1.88)$;

- $\quad$ service for people with a service $\operatorname{dog}(-1.84)$;

- $\quad$ talking to a person with hearing impairment in a separate room $(-1.82)$;

- service up to the last customer, even when the office business hours end (-1.75).

The research shows that the type of disability has a significant impact on the perceived level of disabled customer service, which supports the H3 hypothesis.

Research results also support the $\mathrm{H} 5$ hypothesis that the age of the disabled person affects the assessment of the perceived quality service level. It turns out that young people assess the quality of services provided by the municipal office well, but as they age, their criticism in this area increases. Respectively, people under the age of 20 assess the quality of services in offices as -1.37 ; those in the range of 20-39 assign it the rating of -1.49 ; people aged 40-49 assess the discussed issue at the level of -1.6 ; while disabled people aged 50 and over assess the quality level as -1.63 .

The higher the office's rating compared to others, the higher the disabled clients rate it. People who believe that the surveyed service is much worse than in other offices rated it at -2.46; people claiming that it is not much worse, rated it at the level of -1.96 , while people who think that the service is much better, rate the given office at the level of -1.31 . Research also shows that previous experience and knowledge of good service affect customer assessments. When an individual has previously dealt with facilities in which service is exemplary, then they assess the average service in other places much worse, and vice versa; if a person has never dealt with good service, they tend to treat even poor customer service as something normal. 
Research results do not support the H6 hypothesis regarding the significant impact of the degree of disability on the perceived level of disabled customer service and the H4 hypothesis regarding the significant impact of the disabled person's education on the perceived level of quality of disabled customer service.

Based on our results we think that the municipal offices should be betted adjust they offer to the customer with disability needs. According to European Union documents [9-11], needs of all the people with disability should be fulfilled on the same level regardless of they: disability type, disability level, age etc. Unfortunately, it is not always possible to achieve this rule in researched municipal offices. Persons with disability in older age and with special types of disability (for example, hearing disability) perceive the level of services in municipal offices worse than others. This group have their particular needs which should be fulfilled by the official authorities. They should try to improve the services to better adjust them to their needs. For example, employers should participate in training in the field of handling and dealing with people with hearing disbarment. In addition, they should pay attention to older people - they should inform employers that this group of customers need special care. They in many situations cannot use properly new technologies-computers, mobile devices and when contracting with them we should give them information's in an as simple way as is possible $[103,104]$. In addition, we can send for training not only employers but also organize free training about e-administration and the usage of informatics technology for older people.

The results concerning the relationship between the examined variables of the analysis of the quality of customer service and the assessment of the office compared to other institutions used by the surveyed people support the H6 hypothesis, which reads that the assessment of a given office compared to others has an impact on the perceived level of quality of services provided by a given municipal office for people with disabilities.

The limitations of the research are the fact that it was performed on a sample of cities from one province in one country. Statistically, the sample was reliable, but it is difficult to generalize the results to other regions of Poland. Operationalization of variables is also a limitation of the research. The set of 32 variables identified using the expert method is one of many possible methods of operationalization of service quality issues.

Author Contributions: Conceptualization, R.W. and B.S.-Z.; methodology, R.W. and B.S.-Z.; software, R.W. and B.S.-Z.; validation, R.W. and B.S.-Z.; formal analysis, R.W. and B.S.-Z.; investigation, R.W. and B.S.-Z.; resources, R.W. and B.S.-Z.; data curation, R.W. and B.S.-Z.; writing-original draft preparation, R.W. and B.S.-Z.; writing-review and editing, R.W. and B.S.-Z., visualization, R.W. and B.S.-Z.; supervision, R.W. and B.S.-Z.; project administration, R.W. and B.S.-Z., funding acquisition, R.W. All authors have read and agreed to the published version of the manuscript.

Funding: The analysis in this publication has been made in the course of the research project 'Appointment profile model of factors affecting the level of customer service with a disability in terms of sustainability of public administration on the example of the Silesian Province', UMO2012/05/B/HS4/01144 university symbol PBU-12/ROZ3/2013, funded by the National Center for Science in the OPUS and internal Silesian University of Technology project 13/010/BK_21/0057.

Institutional Review Board Statement: Not applicable.

Informed Consent Statement: Not applicable.

Data Availability Statement: Data is contained within the article.

Conflicts of Interest: The authors declare no conflict of interest.

\section{References}

1. Harayama, Y. Society 5.0: Aiming for a new human-centered society. Hitachi Review 2017, 66, 554-555. Available online: https:/ / www.hitachi.com/rev/archive/2017/r2017_06/trends/index.html (accessed on 12 November 2020).

2. Gandasari, D.; Dwidienawati, D.; Sarwoprasodjo, S. Discourse analysis: The impact of industrial revolution 4.0 and society 5.0 in Indonesia. Int. J. Adv. Sci. Technol. 2020, 29, 5189-5199.

3. Mavrodieva, A.V.; Shaw, R. Disaster and climate change issues in Japan's society 5.0-A discussion. Sustainability 2020, 12, 1893. [CrossRef] 
4. Fukuda, K. Science, technology and innovation ecosystem transformation toward society 5.0. Int. J. Prod. Econ. 2020, 220, 107460. [CrossRef]

5. Fukuyama, M. Society 5.0: Aiming for a new human-centered society. Special article 2. Jpn. Spotlight 2018, 1, 47-50.

6. Granrath, L. Japan's Society 5.0: Going Beyond Industry 4.0. Japan Industry News. 2017. Available online: https://www. japanindustrynews.com/2017/08/japans-society-5-0-going-beyond-industry-4-0/ (accessed on 22 June 2020).

7. Sarfraz, Z.; Sarfraz, A.; Iftikar, H.M.; Akhund, R. Is covid-19 pushing us to the fifth industrial revolution (Society 5.0)? Pak. J. Med Sci. 2021, 37, 1-4. [CrossRef]

8. Trębicka-Postrzygacz, B.; Roguska, A. Człowiek w Środowisku Społecznym: Księga jubileuszowa dedykowana profesorowi Mirosławowi Dyrdzie; Jarmoch, E., Zienkiewicz, J., Eds.; Uniwersytet Przyrodniczo-Humanistyczny w Siedlcach: Siedlce, Poland, 2015; pp. 407-422.

9. European Disability Strategy (2010-2020). Available online: https://eur-lex.europa.eu/legal-content/EN/TXT/?uri= LEGISSUM\%3Aem0047 (accessed on 5 January 2021).

10. Directive (EU) 2019/882 of the European Parliament and of the Council of 17 April 2019 on the Accessibility Requirements for Products and Services. 2019. Available online: https:/ / eur-lex.europa.eu/legal-content/EN/TXT/?uri=CELEX\%3A32019L0882 (accessed on 5 January 2021).

11. Directive (EU) 2016/2102 of the European Parliament and of the Council of 26 October 2016 on the Accessibility of the Web Sides and Mobile Applications of Public Sector Bodies. 2016. Available online: https://eur-lex.europa.eu/legal-content/EN/TXT/ ?uri=uriserv:OJ.L_.2016.327.01.0001.01.ENG (accessed on 5 January 2021).

12. Woźniak, Z. Niepetnosprawność i Niepetnosprawni w Polityce Społecznej. Społeczny Kontekst Medycznego Problemu; Wydawnictwo Naukowe Szkoły Wyższej Psychologii Społecznej Academica: Warszawa, Poland, 2008.

13. Banks, L.M.; Mearkle, R.; Mactaggart, I.; Walsham, M.; Kuper, H.; Blanchet, K. Disability and social protection programmes in low-and middle-income countries: A systematic review. Oxf. Dev. Stud. 2017, 45, 223-239. [CrossRef]

14. Lockwood, E.; Tardi, R. The Inclusion of Persons with Disabilities in the Implementation of the 2030 Agenda for Sustainable Development. Development 2014, 57, 433-437. [CrossRef]

15. Degener, T. A new human rights model of disability. In The United Nations Convention on the Rights of Persons with Disabilities: A Commentary; Della Fina, V., Cera, R., Palmisano, G., Eds.; Springer: Cham, Switzerland, 2017; pp. 41-60.

16. Rimmerman, A. Social Inclusion of People with Disabilities; Cambridge University Press: Cambridge, UK, 2013.

17. Cocq, C.; Ljuslinder, K. Self-representations on social media. Reproducing and challenging discourses on disability. Alter 2020, 12, 71-84. [CrossRef]

18. Rebernik, N.; Szajczyk, M.; Bahillo, A.; Goličnik Marušic, B. Measuring disability inclusion performance in cities using Disability Incursion Evaluation Tool (DIE Tool). Sustainability 2020, 12, 1378. [CrossRef]

19. Vallance, S.; Perkins, H.C.; Dixon, J.E. What is social sustainability? A clarification of concepts. Geoforum 2011, 42, 342-348. [CrossRef]

20. Ustawa z dna 27 Sierpnia 1997 Roku o Rehabilitacji Zawodowej i Społecznej Oraz Zatrudnieniu Osób Niepełnosprawnych Dziennik Ustaw Nr 123. Poz. 776 z Późniejszymi Zmianami w 2002r. 2002. Available online: Prawo.sejm.gov.pl/isap.nsf/ DocDetails.xsp?id=WDU1997123077 (accessed on 15 October 2020).

21. Karta Praw Osób Niepełnosprawnych. Uchwała Sejmu Rzeczypospolitej Polskiej z dnia 1 sierpnia 2006 r. Monit. Polski 1997, 50,475 .

22. Konwencja Nr 159 Międzynarodowej Organizacji Pracy dotycząca rehabilitacji zawodowej i zatrudnienia osób niepełnosprawnych, przyjęta w Genewie dnia 20 czerwca 1983 r. Dziennik Ustaw 2005, 43, 412.

23. Uchwała Sejmu RP w sprawie przeciwdziałania wykluczeniu społecznemu osób niepełnosprawnych z dnia 7 grudnia 2012 r. Monitor Polski 2012, poz. 991.

24. Europejska Karta Społeczna (Zrewidowana), Strasburg, 3 maja 1996. 1996. Available online: https://www.coe.int/t/dghl/ monitoring/socialcharter/Presentation/ESCRBooklet/Polish.pdf (accessed on 12 October 2020).

25. Masala, C.; Petretto, D. From disablement to enablement: Conceptual models of disability in the 20th century. Disabil. Rehabil. 2008, 30, 1233-1244. [CrossRef] [PubMed]

26. Smart, J.F. The power of models of disability. J. Rehabil. 2009, 2, 3-11.

27. Huges, B.; Paterson, K. The Social model of disability and the disappearing Body: Towards a sociology of impairment. J. Disabil. Soc. 2010, 12, 325-340. [CrossRef]

28. Neves da Silva Bampi, L.; Guilhem, D.; Dornelles Alves, E. Social model: A new approach of the disability theme. Revista latino-Am. Enferm. 2010, 18, 816-823. [CrossRef]

29. Woods, R. Exploring how the social model of disability can be re-invigorated: In response to Jonathan Levitt. Disabil. Soc. 2017, 32, 1090-1095. [CrossRef]

30. Oliver, M. The social model of disability: Thirty years on. Disabil. Soc. 2013, 28, 1024-1026. [CrossRef]

31. Retief, M.; Letšosa, R. Models of disability: A brief overview. HTS Theologise Stud./Theological Stud. 2018, 74, 2-8. [CrossRef]

32. Smart Cities World. Creating Inclusive Smart Cities. Smart Cities World, 2018. Available online: https://www.smartcitiesworld. net/news/news/creating-inclusive-smart-cities-336 (accessed on 12 October 2020).

33. Kazmierski, V. From Moore to More: How the social model of disability may be applied to build more inclusive and accessible education systems. Educ. Rev. 2016, 3, 35-41. 
34. Medina-Garcia, M.; Dona-Toledo, L. Equal opportunities in an inclusive and sustainable education system: An explanatory model. Sustainability 2020, 12, 4626. [CrossRef]

35. International Convention of 13 December 2006 on the Rights of Persons with Disabilities. 2016. Available online: https://www. un.org/esa/socdev/enable/documents/tccconvs.pdf (accessed on 12 October 2020).

36. Wolbring, G.; Rybchinski, T. Social sustainability and its indicator's through a disability studies and ability studies lens. Sustainability 2013, 5, 4889-4907. [CrossRef]

37. Wiliński, M. Modele niepełnosprawności: Indywidualny-funkcjonalny-społeczny. In Diagnoza Potrzeb I Modele Pomocy Dla Osób Z Ograniczona Sprawnościa; Brzezińska, A., Kaczan, R., Smoczyńska, K., Eds.; Wydawnictwo Naukowe: Warszawa, Poland, 2010; pp. 15-60.

38. Repeva, A.; Adjidé, N. The challenge of inclusive cities. E3S Web Conf. 2020, 157, 03009. [CrossRef]

39. Dreyer, M.; Mays, C.; Sellke, P.; Renn, O.; Kuhn, R.; Schröter, R.; Hausschild, M.; Dreyer, L.; Wangel, A.; Antunes, P. Literature Review on Social Indicators and Integrated Model of Indicator Selection. 2016. Available online: https://www.greendelta.com/ wp-content/uploads/2017/03/Presentation_PSILCA_Webinar_April2016.pdf (accessed on 22 July 2020).

40. Benoît, C.; Vickery-Niederman, G. Social Sustainability Assessment Literature Review. 2020. Available online: http: //www.sustainabilityconsortium.org/wp-content/themes/sustainability/assets/pdf/whitepapers/Social_Sustainability_ Assessment.pdf (accessed on 21 July 2020).

41. Wolbring, G.; Burke, B. Reflecting on education for sustainable development through two lenses: Ability studies and disability studies. Sustainability 2013, 5, 2327-2342. [CrossRef]

42. Noga, J.; Wolbring, G. An analysis of the united nations conference on sustainable development (Rio+20) discourse using an ability expectation lens. Sustainability 2013, 5, 3615-3639. [CrossRef]

43. Noga, J.; Wolbring, G. The economic and social benefits and the barriers of providing people with disabilities accessible clean water and sanitation. Sustainability 2012, 4, 3023-3041. [CrossRef]

44. Taylor, S.E.; Balandin, S.; Wilson, E.; Murfitt, K. Costumer service communication with customers with disability. J. Consum. Mark. 2019, 36, 160-173. [CrossRef]

45. Goodrich, K.; Ramsey, R. Are consumers with disabilities receiving the services they need? J. Retail. Consum. Serv. 2012, 19, 88-97. [CrossRef]

46. Eskytè, I. Disabled people's vulnerability un the European Single Market: The case of consumer information. J. Consum. Policy 2019, 42, 521-543. [CrossRef]

47. Barnes, C.; Mercer, G. Disability, work and welfare: Challenging the social exclusion of disabled people. Work Employ. Soc. 2005, 19, 527-545. [CrossRef]

48. Goodley, D. Disability Studies: Theorising Disables and Ableism; Routledge: London, UK; New York, NY, USA, 2014.

49. Goodley, D. The disability complex. J. Divers. Gend. Stud. 2018, 5, 5-22. [CrossRef]

50. Fenney Salkeld, D. Sustainable lifestyles for all? Disability equality, sustainability and the limitations of current UK policy. Disabil. Soc. 2016, 31, 447-464. [CrossRef]

51. Goodley, D.; Lawthom, R.; Runswick-Cole, K. Posthuman disability studies. Subjectivity 2014, 7, 342-361. [CrossRef]

52. Goodley, D.; Runswick-Cole, K. Becoming Dishman: Thinking about the human through dis/ability. Discourse: Stud. Cult. Politics Educ. 2016, 37, 1-15.

53. Madrid Declaration on Ethical Standards for Psychiatric Practice. Available online: https://www.google.com/url?sa=t\&rct=

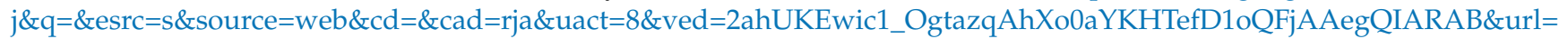
https \%3A\%2F\%2Fwww.wpanet.org\%2Fcurrent-madrid-declaration\&usg=AOvVaw1H3X7D8NLSX-nehNUq_b_g (accessed on 15 October 2020).

54. Uchwała Sejmu Rzeczypospolitej Polskiej z dnia 1 sierpnia 1997 r.-Karta Praw Osób Niepełnosprawnych. Available online: http:/ / isap.sejm.gov.pl/isap.nsf/DocDetails.xsp?id=WMP19970500475 (accessed on 15 October 2020).

55. Moodley, J.; Graham, L. The importance of intersectionality in disability and gender studies. Agenda 2015, 29, 24-33. [CrossRef]

56. Titchkosky, T. Disability, Self and Society; University of Toronto Press: Toronto, ON, Canada, 2003.

57. Watson, N.; Vehmas, S. Challenging the impairment/disability divide. In Routledge Handbook of Disability Studies; Routledge: Abingdon, UK, 2019.

58. Baker, S.M.; Holland, J.; Kaufman-Scarborouqh, C. How consumers with disabilities perceive "welcome" in retail servicescapes: A critical incident study. J. Serv. Mark. 2007, 21, 160-173. [CrossRef]

59. Dennis, C.; Alamanos, E.; Papagiannidis, S.; Bourlakis, M. Does social exclusion influence multiple channel use? The interconnections, with community, happiness, and well-being. J. Bus. Res. 2016, 69, 1061-1070. [CrossRef]

60. Lawthers, A.G.; Pransky, G.S.; Peterson, L.E.; Himmelstein, J.H. Rethinking quality in the context of persons with disability. Int. J. Qual. Health Care 2003, 15, 287-299. [CrossRef]

61. Wolniak, R.; Skotnicka-Zasadzień, B.; Zasadzień, M. Evaluation of the level of quality with regard to architectural barriers according to the degree of disability. In Proceedings of the 3rd International Multidisciplinary Scientific Conference on Social Sciences and Arts SGEM 2016, Vienna, Austria, 6-9 April 2016; STEF92 Technology: Sofia, Bulgaria, 2016; pp. 499-506.

62. Pacana, A.; Andrzej Gazda, A.; Bednárová, L. The impact of quality information on innovatory environment of the public administration. Int. J. Interdiscip. Theory Pract. ITPB 2014, 4, 25-26. 
63. Rosenbaum, M.S.; Banuya, R.; Guttmann, T.S. Customer responses towards disabled frontline employees. Int. Retail Distrib. Manag. 2017, 45, 385-403. [CrossRef]

64. Olivia, S.; Moura, S.P. Assessing Service Quality in a Municipality: A Study Based on the Perceptions of Citizens and Frontline Employees; Firenze University Press: Firenze, Italy, 2008.

65. Garbat, M.; Paszkiewicz, M.A. Jakość życia osób niepełnosprawnych w województwie lubuskim-diagnoza sytuacji materialnobytowej. In Jakość Życia Osób Niepetnosprawnych I Nieprzystosowanych Społecznie; Wydawnictwo Uniwersytetu Marii CurieSkłodowskiej: Lublin, Poland, 2006.

66. Borowicki, P. Jakość życia osób z niepełnosprawnością i ich rodzin w perspektywie zewnętrznej i wewnętrznej-Przegląd wybranych badań. Niepetnosprawność-Zagadnienia, problemy, rozwiąania 2016, 3, 81-91.

67. Pawłowska-Cyprysiak, K.; Konarowska, M.; Żołnierczyk-Zreda, D. Uwarunkowania jakości życia osób niepełnosprawnych ruchowo. Medycyna Pracy 2013, 64, 227-237. [CrossRef] [PubMed]

68. Palak, Z.; Chimicz, D.; Pawlak, A. Wielkość Obszarów We Współczesnej Pedagogice Specjalnej; Wydawnictwo Uniwersytetu Marii Curie-Skłodowskiej: Lublin, Poland, 2012.

69. Smoleń, R. Poczucie jakości życia u młodzieży z upośledzeniem umysłowym. Zeszyty Naukowe Małopolskiej Wyższej Szkoły Ekonomicznej 2011, 18, 273-288.

70. Fridman, C.; Van Puymbrouck, L. The impact of people with disabilities choosing their services on quality of life outcomes. Disabil. Health J. 2019, 2, 187-194. [CrossRef]

71. Philling, D.; Warson, G. Evaluating Quality in Services for Disabled and Older People; Jessica Kingsley Publishers: London, UK, 1995.

72. Mustaffa, W.S.W.; Rahman, R.A.; Wahid, H.A.; Rhouse, S.M.; Hudin, N.S. Exploring disabled students' service quality dimensions: A case of Malaysian higher education institutions (HEIs). Int. J. Acad. Res. Progress. Educ. Dev. 2019, 8, $239-248$.

73. Kalargyrou, V.; Barber, N.A.; Kup, P.J. The impact of disability on guests' perceptions of service quality delivery in the hospitality industry. Int. J. Contemp. Hosp. Manag. 2018, 30, 3632-3655. [CrossRef]

74. Vaughan, E.; Woodruffe-Burton, H. The disabled student experience: Does the SERVQUAL scale measure up? Qual. Assur. Educ. 2011, 19, 28-49. [CrossRef]

75. Kosner, M.; Vigoda-Gadot, E. The provenance of public management and its future: Is public management here to stay? Int. J. Public Sector Manag. 2017, 30, 532-546. [CrossRef]

76. Giauque, D. New public management and organizational regulation: The liberal bureaucracy. Int. Rev. Adm. Sci. 2003, 69, 567-592. [CrossRef]

77. Radu, A.M.; Pólkowski, Z. Theoretical, Technical and Practical Aspects of E-Administration. Zeszyty Naukowe Dolnośląskiej Wyższej Szkoły Przedsiębiorczości i Techniki w Polkowicach. Studia z Nauk Społecznych 2014, 7, 185-210.

78. Linstone, H.A.; Turoff, M. The Delphi Method: Techniques and Applications; Addison-Wesley Educational Publisher: London, UK, 1975.

79. Keeney, S.; Hasson, F.; McKenna, H. The Delphi Technique in Nursing and Health Research; Blackwell Publishing: New Delhi, India, 2011.

80. Bradley, L.; Stewart, K. A Delphi study of internet banking. Mark. Intell. Plan. 2013, 21, 272-281. [CrossRef]

81. Hsu, C.C.; Sandford, B.A. The Delphi technique: Making sense of consensus. Pract. Assess. Res. Eval. 2007, 10, 1-8.

82. Wagner, R.M. Applied Statistic. From Bivariate through Multivariate Techniques; SAGE: Los Angeles, CA, USA, 2011.

83. Herkenhoff, L.; Fogli, J. Applied Statistic for Business and Management Using Microsoft Excel; Springer: New York, NY, USA, 2013.

84. Wolniak, R.; Jonek-Kowalska, I. The level of the quality of life in the city and its monitoring. Innovations 2020, 1-23. [CrossRef]

85. Munoz, R.M.; Salinero, Y.; Fernandez, M.V. Sustainability, entrepreneurship and disability: A new challenge for universities. Sustainability 2020, 12, 2494. [CrossRef]

86. Agangiba, M.; Kabanda, S. Towards a conceptual framework for e-government accessibility for persons with disabilities in developing countries. In Proceedings of the International Conference on Information Resources Management, CONF-IRM 2016, Cape Town, South Africa, 18-20 May 2016; pp. 125-138.

87. Rubaii-Barrett, N.; Wise, L.R. Disability access and e-government: An empirical analysis of state practices. J. Disabil. Policy Stud. 2008, 19, 52-64. [CrossRef]

88. Agangiba, M.; Kabanda, S.; Brown, I. Experiences of persons with disabilities in accessing e-government services in Ghana. In Proceedings of the 26th European Conference on Information Systems (ECIS2018), Portsmouth, UK, 23-28 June 2018; pp. 1-16.

89. Habib, M.A.; Rahaman, S.; Chaklader, A. Client's satisfaction with disability care services available in a selected district in Bangladesh. Int. J. Epidemiol. Res. 2017, 4, 199-204. [CrossRef]

90. Yusuf, Y. Effect of public services quality on satisfaction and its implication on public trust. J. Bus. Manag. 2017, 19, 14-20. [CrossRef]

91. Sharif, S.; Hazlina, A.; Soaad, S.; Yahja, S. Multivariative Statistic for Researchers; Penerbit Universiti Utara Malaysia: Sintok, Malaysia, 2016.

92. Tokunaga, H.T. Fundamental Statistics for the Social and Behavioral Sciences; SAGE Publications: Singapore, 2016.

93. Gravetter, F.J.; Wallnau, K.B. Statistics for the Behavioral Sciences; Cengage Learning: Boston, MA, USA, 2016.

94. Peck, R.; Short, T. Statistics: Learning from Data; Cengage: Boston, MA, USA, 2018.

95. Keller, G. Statistics for Management and Economics; Cenage: Boston, MA, USA, 2017.

96. Frankfort-Nachmias, C.; Leon-Guerero, A. Social Statistics for a Diverse Society; SAGE: Los Angeles, CA, USA, 2018. 
97. Wolniak, R.; Skotnicka-Zasadzień, B.; Zasadzień, M. Problems of the functioning of e-administration in the Silesian region of Poland from the perspective of a person with disabilities. Transylv. Rev. Adm. Sci. 2019, 57E, 137-155. [CrossRef]

98. Wolniak, R. The analysis of architectural barriers in Pszczyna Municipial Office from disable person point of view. Sil. Univ. Technol. Sci. Pap. Organ. Manag. 2016, 87, 429-441.

99. Stecuła, K. Decision-making dilemmas in mining enterprise and environmental issues, i.e. green thinking in mining. In Proceedings of the 18th International Multidisciplinary Scientific Geoconference, SGEM 2018, Albena, Bulgaria, 30 June-9 July 2018 ; Volume 18, pp. 357-364.

100. Dobosz, M.; Saja, P.; Pacana, A. Improvement of health and safety conditions at selected workplaces. Prod. Manag. Eng. Sci. 2016, $5,55-65$.

101. Pacana, A.; Ulewicz, R. Analysis of causes and effects of implementation of the quality management system complaint with ISO 9001. Pol. J. Manag. Stud. 2020, 21, 283-296. [CrossRef]

102. Noorjahan, M. A bio metric based approach for using captcha-To enhance accessibility for the visually impaired. Disabil. Rehabil. Assist. Technol. 2020, 15, 153-156. [CrossRef] [PubMed]

103. Volkova, O.A.; Koneva, T.N.; Kopytov, A.A.; Artemova, Y.S. Confidentiality and consent in the care of the adolescent patient. Problemy Sotsial'noi Gigieny, Zdravookhraneniia I Istorii Meditsiny 2019, 27, 404-407.

104. Tscymbalystov, A.V.; Volkova, O.A.; Besschetnova, O.V.; Kopytov, A.A.; Artyomova, Y.S. Social interaction as a factor of elderly and disabled people's activity in receiving cardiovascular health services in Russia. J. Comput. Theor. Nanosci. 2019, 16, 4889-4900. 